\title{
Modelling of sorption-enhanced steam methane reforming in a fixed bed reactor network integrated with fuel cell
}

\section{Giuseppe Diglio $^{a}$, Dawid P. Hanak ${ }^{\mathrm{b}}$, Piero Bareschino ${ }^{\mathrm{a}}$, Francesco Pepe ${ }^{\mathrm{a}}$, Fabio Montagnaro ${ }^{\mathrm{c}}$, Vasilije Manovic ${ }^{\mathrm{b}}$ **}

${ }^{a}$ Dipartimento di Ingegneria, Università degli Studi del Sannio, Piazza Roma 21, 82100 Benevento, Italy

${ }^{\mathrm{b}}$ Combustion and CCS Centre, Cranfield University, Cranfield MK43 0AL, United Kingdom

\footnotetext{
${ }^{c}$ Dipartimento di Scienze Chimiche, Università degli Studi di Napoli Federico II, Complesso Universitario di Monte Sant'Angelo, 80126 Napoli, Italy
}

Applied Energy, 210, 1-15

*Corresponding Author: V. Manovic (v.manovic@cranfield.ac.uk) 


\begin{abstract}
In this study sorption-enhanced steam methane reforming (SE-SMR) in fixed beds is investigated by means of 1D numerical modelling, and the model is validated with the data reported in the literature. Isothermal conditions $(973 \mathrm{~K})$ are considered, and the equilibrium between the carbonation and calcination stages is shifted by a pressure swing: $3.5 \cdot 10^{6} \mathrm{~Pa}$ and $1013 \mathrm{~Pa}$, respectively. The results showed that under these operating conditions at least 8 reactors in parallel are required to continuously produce a high-purity stream of $\mathrm{H}_{2}$, and a separated stream of concentrated $\mathrm{CO}_{2}$. The average $\mathrm{H}_{2}$ purity is 0.92 , whilst the average $\mathrm{H}_{2}$ yield and selectivity are 2.9 mol $_{\mathrm{H} 2} \cdot \mathrm{mol}_{\mathrm{CH} 4}{ }^{-1}$ and $90 \%$, respectively. A thermodynamic analysis was performed, which highlighted that, by using a portion of the produced $\mathrm{H}_{2}$ (about $0.4 \operatorname{mol}_{\mathrm{H} 2} \cdot \operatorname{mol}_{\mathrm{CH} 4}{ }^{-1}$ ), it is possible to fully cover heat and power demands of the process, making it completely energy self-sufficient. In the case when the proposed SE-SMR is integrated with a solid oxide fuel cell, net power generation at the scale of $\sim 950 \mathrm{~kW}_{\mathrm{el}}$ can be achieved with a net efficiency of the entire system of $51 \%$, with the important feature that $\mathrm{CO}_{2}$ is concentrated.
\end{abstract}

Keywords: Sorption-Enhanced Steam Methane Reforming; Fixed Bed Reactor network; Hydrogen; Solid Oxide Fuel Cell; Energetic self-sufficiency. 


\section{Nomenclature}
$\mathrm{A}_{\mathrm{a}}$
Aspect ratio of the external surface area to the volume of the reactor wall, $\mathrm{m}^{-1}$
$\mathrm{A}_{\mathrm{EH}}$
Heat surface area required by CAS, $\mathrm{m}^{2}$
$\mathrm{A}_{\mathrm{r}}$
Surface of reactor vessel, $\mathrm{m}^{2}$
$\mathrm{A}_{\mathrm{w}}$
Aspect ratio of the internal surface area to the volume of the reactor wall, $\mathrm{m}^{-1}$
$\mathrm{C}_{\mathrm{i}}$
Concentration of species $\mathrm{i}, \mathrm{mol} \cdot \mathrm{m}^{-3}$
$c_{p}$
Heat capacity, $\mathrm{J} \cdot \mathrm{kg}^{-1} \cdot \mathrm{K}^{-1}$
$\mathrm{D}_{\mathrm{ax}}$
Axial dispersion coefficient, $\mathrm{m}^{2} \cdot \mathrm{s}^{-1}$
d
Diameter, $\mathrm{m}$
$E_{a, j}$
Activation energy of reaction $\mathrm{j}, \mathrm{J} \cdot \mathrm{mol}^{-1}$
$\mathrm{E}_{\mathrm{D}}$
Electric power demand of vacuum pump, $\mathrm{W}_{\mathrm{el}}$
$E_{\text {net }}$
Net alternate current power production, $\mathrm{W}_{\mathrm{el}}$
$\mathrm{E}_{\mathrm{SOFC}}$
SOFC alternate current power, $\mathrm{W}_{\mathrm{el}}$
F
Faraday constant, A.s. $\mathrm{mol}^{-1}$
$f_{u}$
SOFC fuel utilisation
G
Mass flux of the gas phase, $\mathrm{kg} \cdot \mathrm{m}^{-2} \cdot \mathrm{s}^{-1}$
g
Acceleration due to gravity, $\mathrm{m} \cdot \mathrm{s}^{-2}$
$\mathrm{H}_{\text {ext }}$
External heating and power, $\mathrm{J} \cdot \mathrm{mol}_{\mathrm{CH} 4}{ }^{-1}$
$\mathrm{h}_{\mathrm{f}}$
Gas-solid heat transfer coefficient, $\mathrm{W} \cdot \mathrm{m}^{-2} \cdot \mathrm{K}^{-1}$
$\mathrm{h}_{\mathrm{i}}$
Enthalpy of gas species i, $\mathrm{J} \cdot \mathrm{mol}^{-1}$
$\mathrm{h}_{\mathrm{ext}} \quad$ External convective heat transfer coefficient, $\mathrm{W} \cdot \mathrm{m}^{-2} \cdot \mathrm{K}^{-1}$
$\mathrm{h}_{\mathrm{m}} \quad$ Gas-solid mass transfer coefficient, $\mathrm{m} \cdot \mathrm{s}^{-1}$
$\mathrm{h}_{\mathrm{w}} \quad$ Internal convective heat transfer coefficient, $\mathrm{W} \cdot \mathrm{m}^{-2} \cdot \mathrm{K}^{-1}$ 
$\mathrm{i}$

j

$\mathrm{K}_{\mathrm{i}}$

$\mathrm{K}_{\mathrm{j}}$

$\mathrm{k}_{\mathrm{j}}$

L

LHV

M

$\dot{\mathrm{m}}$

$\mathrm{m}_{\mathrm{s}}$

$\mathrm{N}_{\mathrm{Me}}$

$\mathrm{N}_{\mathrm{R}}$

$\dot{\mathrm{n}}_{\mathrm{CH}_{4} \text {,in }}$

$\dot{\mathrm{n}}_{\mathrm{H} 2 \text {,SE-SMR }}$

$\dot{\mathrm{n}}_{\mathrm{CH}_{4}, \mathrm{SE}-\mathrm{SMR}}$

P

$\mathrm{P}_{\mathrm{i}}$

$\mathrm{P}_{0}$

$\operatorname{Pr}$

Q

Q

$\dot{\mathrm{Q}}_{\text {burner }}$

$\dot{\mathrm{Q}}_{\mathrm{f}}$

$\dot{Q}_{S E-S M R}$

$\dot{\mathrm{Q}}_{\mathrm{SOFC}}$

$\dot{\mathrm{Q}}_{\text {ref }}$

Gas species $\left(\mathrm{CH}_{4}, \mathrm{H}_{2} \mathrm{O}, \mathrm{H}_{2}, \mathrm{CO}, \mathrm{CO}_{2}\right)$

Reaction (SMR, WGS, OSMR, CR, CAR)

Adsorption coefficient of species $i$

Equilibrium constant of reaction $\mathrm{j}$

Rate constant of reaction $\mathrm{j}$

Reactor length, m

Lower Heating Value, $\mathrm{J} \cdot \mathrm{mol}^{-1}$

Molecular weight, $\mathrm{kg} \cdot \mathrm{mol}^{-1}$

Gas mass flow rate, $\mathrm{kg} \cdot \mathrm{s}^{-1}$

Mass of solid in the reactor, $\mathrm{kg}$

Mears number, -

Number of reactors, -

Inlet $\mathrm{CH}_{4}$ molar flow rate, $\mathrm{mol} \cdot \mathrm{s}^{-1}$

$\mathrm{H}_{2}$ molar flow rate at the outlet of SE-SMR process, mol·s ${ }^{-1}$

$\mathrm{CH}_{4}$ molar flow rate at the outlet of SE-SMR process, mol.s ${ }^{-1}$

Pressure, $\mathrm{Pa}$

Partial pressure of gas species i, bar

Standard pressure, $\mathrm{Pa}$

Prandtl number, -

Volumetric flow rate, $\mathrm{m}^{3} \cdot \mathrm{s}^{-1}$

Thermal power, $\mathrm{W}_{\text {th }}$

Thermal power generated by external burner, $\mathrm{W}_{\text {th }}$

Thermal power required to warm up feed gas streams, $\mathrm{W}_{\text {th }}$

Thermal power required by SE-SMR process, $\mathrm{W}_{\text {th }}$

Thermal power generated by SOFC, $\mathrm{W}_{\text {th }}$

Thermal power required by SOFC internal reforming process, $\mathrm{W}_{\text {th }}$ 


\begin{tabular}{|c|c|}
\hline $\mathrm{Ra}$ & Rayleigh number, - \\
\hline $\operatorname{Re}$ & Reynolds number, - \\
\hline $\mathrm{R}_{\mathrm{g}}$ & Ideal gas constant, $\mathrm{J} \cdot \mathrm{mol}^{-1} \cdot \mathrm{K}^{-1}$ \\
\hline $\mathrm{R}_{\mathrm{j}}$ & Reaction rate of reaction $\mathrm{j}, \mathrm{mol} \cdot \mathrm{kg}^{-1} \cdot \mathrm{s}^{-1}$ \\
\hline$r_{i}$ & Rate of formation or consumption of species $\mathrm{i}, \mathrm{mol} \cdot \mathrm{m}^{-3} \cdot \mathrm{s}^{-1}$ \\
\hline $\mathrm{Sc}$ & Schmidt number, - \\
\hline $\mathrm{S}_{\mathrm{H} 2}$ & $\mathrm{H}_{2}$ selectivity, $\%$ \\
\hline $\mathrm{s}_{\mathrm{s}}$ & Reactor wall thickness, m \\
\hline $\mathrm{U}$ & External overall heat transfer coefficient from the wall to the ambient air, $\mathrm{W} \cdot \mathrm{m}^{-2} \cdot \mathrm{K}^{-1}$ \\
\hline $\mathrm{u}$ & Gas superficial velocity, $\mathrm{m} \cdot \mathrm{s}^{-1}$ \\
\hline $\mathrm{T}$ & Temperature, $\mathrm{K}$ \\
\hline $\mathrm{T}_{\mathrm{w}}$ & Temperature of the reactor wall, $\mathrm{K}$ \\
\hline $\mathrm{t}$ & Time, s \\
\hline$t_{\text {calc }}$ & Period of calcination stage, $\mathrm{s}$ \\
\hline$t_{\text {carb }}$ & Period of carbonation stage, $\mathrm{s}$ \\
\hline $\mathrm{X}_{\text {sorb }}$ & Sorbent conversion degree, $\%$ \\
\hline $\mathrm{X}_{\max }$ & Maximum sorbent conversion, $\%$ \\
\hline $\mathrm{X}_{\mathrm{CH} 4}$ & Methane conversion, $\%$ \\
\hline $\mathrm{V}_{\mathrm{r}}$ & Reactor volume, $\mathrm{m}^{3}$ \\
\hline $\mathrm{V}_{\text {loss }}$ & Fuel Cell voltage loss, V \\
\hline $\mathrm{V}_{\mathrm{SOFC}}$ & SOFC voltage, $\mathrm{V}$ \\
\hline $\mathrm{y}_{\mathrm{i}}$ & Molar fraction of gas species I, - \\
\hline $\mathrm{z}$ & Axial spatial variable, $\mathrm{m}$ \\
\hline \multicolumn{2}{|c|}{ Greek letters } \\
\hline$\alpha_{\mathrm{a}}$ & Thermal diffusivity at the film temperature, $\mathrm{m}^{2} \cdot \mathrm{s}^{-1}$ \\
\hline$\beta_{\mathrm{b}}$ & Thermal expansion coefficient, $\mathrm{K}^{-1}$ \\
\hline
\end{tabular}




\begin{tabular}{|c|c|}
\hline$\gamma_{\mathrm{el}, \mathrm{SOFC}}$ & SOFC electrical efficiency, $\%$ \\
\hline$\gamma_{\text {inv }}$ & Inverter efficiency, $\%$ \\
\hline$\gamma_{\mathrm{ref}}$ & Reforming process efficiency, $\%$ \\
\hline$\Delta \mathrm{G}_{\mathrm{f}}^{0}$ & Change in molar Gibbs free energy of formation, $\mathrm{J} \cdot \mathrm{mol}^{-1}$ \\
\hline$\Delta \mathrm{H}^{0}$ & Standard enthalpy of reaction, $\mathrm{J} \cdot \mathrm{mol}^{-1}$ \\
\hline$\Delta \mathrm{H}_{\mathrm{RJ}}$ & Enthalpy of reaction $\mathrm{j}, \mathrm{J} \cdot \mathrm{mol}^{-1}$ \\
\hline$\Delta \mathrm{P}$ & Maximum pressure drop, $\mathrm{Pa}$ \\
\hline$\varepsilon_{\mathrm{g}}$ & Bed void fraction, - \\
\hline$\zeta$ & Dimensionless axial spatial coordinate, - \\
\hline$\eta_{\mathrm{H} 2}$ & $\mathrm{H}_{2}$ yield, $\operatorname{mol}_{\mathrm{H} 2} \cdot \operatorname{mol}_{\mathrm{CH} 4}{ }^{-1}$ \\
\hline$\eta_{\mathrm{H} 2 \text {,equivalent }}$ & $\mathrm{H}_{2}$-equivalent yield, mol $_{\mathrm{H} 2} \cdot \mathrm{mol}_{\mathrm{CH} 4}{ }^{-1}$ \\
\hline$\theta$ & Steam-to-methane feed ratio during carbonation stage, - \\
\hline 1 & Partition ratio, - \\
\hline$\lambda_{\mathrm{amb}}$ & External air thermal conductivity, $\mathrm{W} \cdot \mathrm{m}^{-1} \cdot \mathrm{K}^{-1}$ \\
\hline$\lambda_{\mathrm{ax}}$ & Axial heat dispersion coefficient, $\mathrm{W} \cdot \mathrm{m}^{-1} \cdot \mathrm{K}^{-1}$ \\
\hline$\lambda_{\mathrm{w}}$ & Reactor wall thermal conductivity, $\mathrm{W} \cdot \mathrm{m}^{-1} \cdot \mathrm{K}^{-1}$ \\
\hline$\mu_{\mathrm{g}}$ & Gas viscosity, $\mathrm{Pa} \cdot \mathrm{s}$ \\
\hline$v_{\mathrm{v}}$ & Kinematic viscosity at the film temperature, $\mathrm{m}^{2} \cdot \mathrm{s}^{-1}$ \\
\hline$\rho$ & Density, $\mathrm{kg} \cdot \mathrm{m}^{-3}$ \\
\hline$\sigma$ & Internal diffusion effectiveness factor, - \\
\hline$\tau_{\text {car } / \text { calc }}$ & Period of the carbonation/reforming and calcination cycle, $\mathrm{s}$ \\
\hline$\tau_{\mathrm{SE}-\mathrm{SMR}}$ & Total Period of the SE-SMR process, $\mathrm{s}$ \\
\hline$\phi$ & Portion of reactors operating in the considered stage \\
\hline$\varphi$ & Heat transfer effectiveness factor, - \\
\hline$\psi$ & Steam-to- $\mathrm{CO}_{2}$ feed ratio during calcination stage, - \\
\hline
\end{tabular}


$\omega_{\mathrm{y}} \quad$ Mass fraction of component y (sorbent or catalyst), -

Subscripts

\begin{tabular}{ll} 
amb & Ambient \\
cat & Catalyst \\
$\mathrm{g}$ & Equilibrium \\
in & Gas \\
obs & Inlet \\
p & Observed \\
r & Particle \\
s & Reactor \\
sorb & Solid \\
out & Sorbent \\
w & Outlet \\
\hline
\end{tabular}

Acronyms

CALCR CALCination Reaction

CAS CAlcination Stage

CG-CO $\mathrm{CO}_{2} \quad$ Carbon Gasification by $\mathrm{CO}_{2}$

CG-S Carbon Gasification by Steam

CLR Chemical Looping Reforming

CR Carbonation Reaction

CS Carbonation Stage

D Depressurisation stage

DR Dry Reforming

MD Methane Decomposition

OSMR Overall Steam Methane Reforming 
PR PRessurisation stage

PS Purge Stage

SE-SMR Sorption-Enhanced Steam Methane Reforming

SMR Steam Methane Reforming

SOFC Solid Oxide Fuel Cell

WGS Water Gas Shift 


\section{Introduction}

Currently, the interest in hydrogen production technologies is on the increase, since $\mathrm{H}_{2}$ is considered as an environmentally friendly alternative for various industrial processes. The current literature reports that $\mathrm{H}_{2}$ can be used as fuel for power generation [1], as chemical raw material for the synthesis of ammonia or the refining of crude oil [1], as well as for fuel cell applications [2]. However, $\mathrm{H}_{2}$ is just an energy carrier, a secondary form of energy that has to be produced [3], and methane was conventionally used as feedstock for this purpose due to both its abundance and high $\mathrm{H}: \mathrm{C}$ ratio.

Steam methane reforming (SMR) is a prevailing $\mathrm{H}_{2}$ production technology, accounting for over $40 \%$ of the world's production [4]: $\mathrm{CH}_{4}$ and $\mathrm{H}_{2} \mathrm{O}$ are catalytically reformed in a multi-tubular reactor packed with a Ni-based catalyst and operated at $1073 \mathrm{~K}-1223 \mathrm{~K}$. The heat needed for the endothermic reforming reactions, which is usually supplied by an external furnace, and the required gas post-processing unit are the main drawbacks of this process. The effluent gas of SMR is syngas, a mixture of $\mathrm{H}_{2}$ and $\mathrm{CO}(\sim 12 \%)$; therefore, a further post-processing unit, which consists of at least one water gas shift reactor to convert $\mathrm{CO}$ to $\mathrm{CO}_{2}$ and a $\mathrm{CO}_{2}$ separation unit, is required to obtain an enriched- $\mathrm{H}_{2}$ gas stream [5].

To overcome these issues, many alternatives have been proposed in the literature, among which chemical looping reforming (CLR) seems to be the most promising. CLR is a cyclic process in which a Ni-based solid material acting as both catalyst (usually) and oxygen carrier is alternatively oxidised by air (exothermic reaction) and reduced by methane (endothermic reaction). Generally, this process is carried out in a dual interconnected fluidised bed reactor operated under autothermal conditions. In this process, the catalyst is continuously circulated between an air reactor and a fuel reactor in such a way that the heat generated by the exothermic oxidation of the oxygen carrier in the air reactor is used to drive endothermic steam reforming reactions in the fuel reactor [6]. Recently, Diglio et al. [7] analysed the CLR process in a fixed bed reactor system, where the solid material is stationary and exposed to oxidising and reforming conditions by switching the feed gas stream. However, it should be noted that albeit CLR is autothermally operated, thus eliminating the need of an external heat source, the outlet gas stream is syngas and a gas post-processing unit is still needed. Recently, Spallina et al. [8] explored the possibility to address this drawback by developing a fixed bed CLR concept. The authors proposed employing three reactors in which the oxidation/reduction/reforming stages are sequentially carried out in order to obtain a syngas stream. A further water gas shift reactor converts $\mathrm{CO}$ content of this stream to $\mathrm{CO}_{2}$, which is adsorbed in a subsequent pressure swing adsorption stage, obtaining a $\mathrm{H}_{2}$-rich gas stream at the outlet of the system. 
By using pressure swing adsorption, the use of one of the most expensive operations of $\mathrm{H}_{2}$ production processes, i.e., the $\mathrm{CO}_{2}$ separation unit, is avoided.

To reduce the operational complexity and the cost of the gas post-processing unit, an interesting alternative for the production of a high-purity $\mathrm{H}_{2}$ stream is represented by sorptionenhanced steam methane reforming (SE-SMR) [9]: in this process, the solid material is a hybrid mixture of reforming catalyst and $\mathrm{CO}_{2}$ solid adsorbent in order to carry out reforming and $\mathrm{CO}_{2}$ adsorption simultaneously. The latter step is conducted via carbonation of $\mathrm{CaO}$ that is the most commonly used sorbent material. A high-purity $\mathrm{H}_{2}$ stream can be produced at operating temperature ranging between $723 \mathrm{~K}$ and $1023 \mathrm{~K}$, thus eliminating the need of a gas post-processing unit [10]. Subsequently, the sorbent material is regenerated via the reverse of the carbonation reaction, i.e., the calcination reaction, producing a stream of concentrated $\mathrm{CO}_{2}$. While the $\mathrm{H}_{2}$ production and $\mathrm{CO}_{2}$ adsorption step is autothermal, since the reforming process is driven by the exothermic carbonation reaction, the heat required by the endothermic calcination reaction represents one of the drawbacks of SE-SMR [11]. Another challenge for the process is the loss of sorbent reactivity over a series of carbonation/calcination cycles [12]. It is important to stress here that SE-SMR is a different process with respect to CLR above-presented, although with the same purpose, i.e., $\mathrm{H}_{2}$ production. In this paper, only SE-SMR is analysed and simulated. Many experimental and numerical attempts have been undertaken and presented in the literature in order to evaluate the feasibility of the SE-SMR process in a fluidised bed arrangement. Johnsen and co-workers investigated the performance of SESMR in a dual fluidised bed reactor layout, both experimentally [13] and numerically [14], reporting important indications in terms of solid circulation rate, operation temperature and make-up of the fresh sorbent. Solsvik et al. [15] developed a 1D Euler two-fluid model for reactive gas-solid flows in bubbling fluidised bed reactors, evaluating the effect of the operating temperatures and pressures, the density and size of the solid material particles, and gas fluidisation velocity on the performance of SE-SMR. Esteban-Díez et al. [16] numerically and experimental studied sorption-enhanced steam reforming process in a fluidised bed reactor, but using bio-oil as fuel. The authors highlighted that a hydrogen purity around $99 \%$ can be obtained at operating temperature of $850 \mathrm{~K}$ and atmospheric pressure.

Recently, fixed beds were proposed as a feasible alternative to fluidised beds since they can be more easily operated at high pressures, there is no need for the gas/solid separation step and operational problems caused by attrition and elutriation of the solid material are negligible $[17,18]$. Balasubramanian et al. [19] carried out an experimental study on the SE-SMR process using a laboratory-scale fixed bed reactor. The authors claimed that a gas high-purity $\mathrm{H}_{2}$ stream $\left(y_{H_{2}} \sim 95 \%\right)$ can be obtained and highlighted that the resulting purity is relatively independent of the operating 
temperatures in the range $823 \mathrm{~K}-1023 \mathrm{~K}$. Fernandez et al. [20] investigated a simultaneous calcination-reduction process in a laboratory-scale fixed bed reactor, finding that the exothermic reduction of $\mathrm{CuO}$ directly supplies the heat required for sorbent regeneration. Li et al. [21] studied the SE-SMR process in a laboratory-scale experimental apparatus employing two parallel fixed beds placed inside a tubular electric furnace: while one reactor was operated at $900 \mathrm{~K}$ and used to carry out the carbonation/reforming reactions, the calcination reaction was run in the other one, which was operated at $1023 \mathrm{~K}$; by switching the operating conditions at a fixed period, the authors reported that continuous production can be achieved, with a $\mathrm{H}_{2}$-purity of $\sim 90 \%$. Antzara et al. [22] experimentally demonstrated in a bench-scale fixed bed reactor the feasibility of a novel SE-SMR process in which a second chemical-loop of $\mathrm{NiO}$-based oxygen carrier provides the heat required by the endothermic sorbent regeneration stage. Barelli et al. [23] evaluated the performance of a novel sorbent based on incorporation of $\mathrm{CaO}$ particles into calcium aluminates under a multi-cycle SE-SMR process in a fixed bed. The authors claimed that the novel sorbent showed higher $\mathrm{H}_{2}$ purity and $\mathrm{CO}_{2}$ adsorption than conventional materials. Fernandez et al. [24] numerically investigated the carbonation/reforming stage of SE-SMR in an autothermal fixed bed, obtaining at the outlet of the reactor a $\mathrm{H}_{2}$ molar fraction and methane conversion of $95 \%$ and $85 \%$, respectively, under operating conditions of $923 \mathrm{~K}$ and 3.5 $10^{6} \mathrm{~Pa}$. Moreover, Alcaron and Fernandez [25] carried out a sensitivity analysis on the main parameters affecting the performance of the calcination reaction operated simultaneously with $\mathrm{CuO}$ reduction in a fixed reactor. $\mathrm{Li}$ and Cai [26] developed a numerical model to investigate the effect of multiple carbonation/calcination steps on the gas composition at the outlet of a single fixed bed.

Currently, fuel cells are under the spotlight as environmentally friendly power generation systems [2]. Among several fuel cell technologies, solid oxide fuel cells (SOFC) are the most used due to a wide range of operating temperatures $(873 \mathrm{~K}-1123 \mathrm{~K})$ that not only allows the use of a variety of fuels, but also makes them suitable for integration with gas turbines [27]. So far, only small stationary SOFC units for combined heat and power generation applications have been deployed [28], but recently large pressurised SOFCs are being developed, since they are characterised by higher electrical net efficiencies and lower costs [29]. A promising application of SOFC using syngas as fuel was demonstrated by Barelli et al. [30], which experimentally studied an innovative cogeneration system based on a SOFC coupled with $\mathrm{CO}_{2}$ dry reforming.

The above literature review shows that although SE-SMR in fixed beds has recently received great attention, this process still poses a number of unsolved challenges. In particular, to the best of the authors' knowledge, no study presented in the open literature: 
I. assessed the operational strategy required by large-scale reactors to switch between the carbonation and calcination stages;

II. evaluated the minimum number of reactors needed to obtain continuous $\mathrm{H}_{2}$ production when the SE-SMR process is operated in fixed beds;

III. and, most importantly, proposed coupling SOFC with SE-SMR for power generation with near-zero- $\mathrm{CO}_{2}$ emissions.

This paper aims to numerically address these points with a view to advancing the scale-up and commercialisation of the technology. Moreover, although recent theoretical and experimental work dealt with the SE-SMR process in a fixed bed, no paper carried out the process without supplying heat from an external source as in the case hereby presented. Indeed, this work explores the feasibility of the SE-SMR process in a network of fixed beds in order to provide parameters required for the design and development of the proposed system layout under energy self-sufficiency conditions. The performance of fuel cells as a potential alternative for the utilisation of produced $\mathrm{H}_{2}$ is also investigated. A full-scale integration of the SE-SMR process with SOFC is analysed. The produced $\mathrm{H}_{2}$ was split into two streams, one fed to an external burner to cover the heat demand of the system, the other one sent to the SOFC. This arrangement demonstrated high efficiency, not only for the $\mathrm{SOFC}$, but also for the entire hybrid system. The net fuel cell power production with near-zero- $\mathrm{CO}_{2}$ emission represents the output of the proposed layout.

\section{SE-SMR operation strategy and process integration}

\subsection{SE-SMR operation strategy}

In this work, it is proposed to operate the SE-SMR process in a fixed bed network, where the solid material (Ni-catalyst/Ca-sorbent) is stationary and is exposed to cyclic carbonation/reforming and calcination conditions by a pressure swing at $973 \mathrm{~K}$ as shown in Figure 1. The fixed bed reactor is fed by a mixture of methane and steam during period $t_{c a r b}$ (carbonation time) and operated at high pressure $\left(3.5 \cdot 10^{6} \mathrm{~Pa}\right)$ for the steam methane reforming and carbonation reactions to occur. Highpressure operation is a common practice in large-scale applications to reduce reactor size and cost of $\mathrm{H}_{2}$ production [31]. Then, to shift the equilibrium towards calcination, the feed is changed to a mixture of steam and $\mathrm{CO}_{2}$, and the pressure is reduced to below $1013 \mathrm{~Pa}$; thus, during the period $t_{\text {calc }}$ (calcination time) the calcination reaction occurs. 


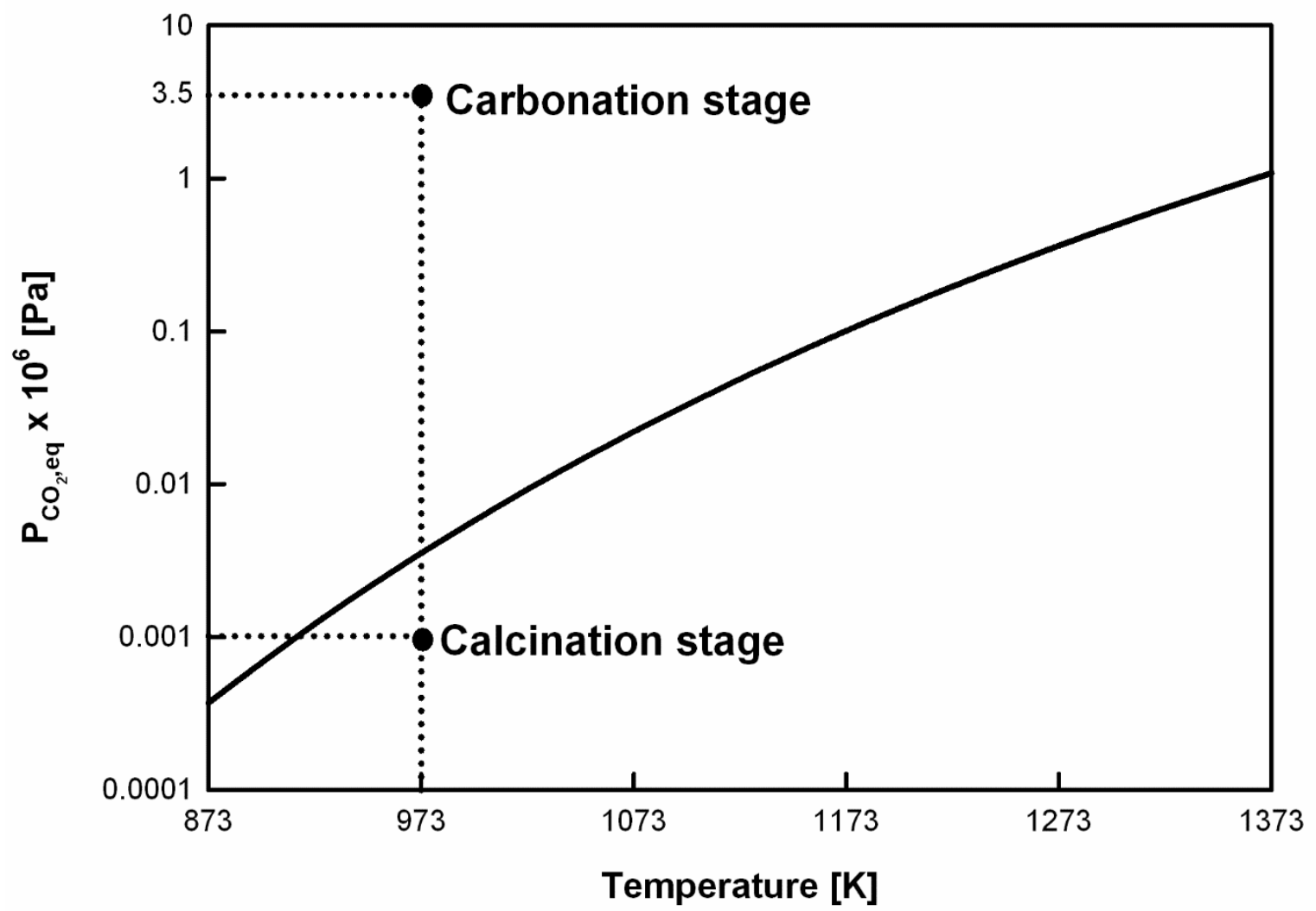

Figure 1 - Carbonation and calcination operating conditions on the $\mathrm{CO}_{2}$ equilibrium partial pressure-temperature diagram [32].

The lower temperature required to regenerate the sorbent (see Figure 1) is one of the advantages of sub-atmospheric calcination, which mitigates the sorbent sintering effect seen at high temperatures [33]. Moreover, there is considerable evidence in the literature that $\mathrm{CaO}$ obtained from calcination under vacuum has a higher reactivity, thus being less affected by sorbent reactivity decay during several carbonation/calcination cycles [34-36].

The feasibility of the calcination reaction under sub-atmospheric conditions in a fixed bed was first demonstrated by Sakadjian et al. [36] and then patented by Fan et al. [37]. The reactor should be cyclically operated following six stages: (1) carbonation stage (CS); (2) purge stage (PS) for $\mathrm{H}_{2}$ that is still present in the reactor; (3) depressurisation (D) to obtain vacuum condition in the bed; (4) calcination stage (CAS); (5) purge stage for steam and $\mathrm{CO}_{2}$ that are still present in the reactor; and (6) pressurisation $(\mathrm{PR})$ to raise the pressure to the value at which CS is operated $\left(3.5 \cdot 10^{6} \mathrm{~Pa}\right)$. PS, D and PR do not change the concentrations of chemical species, since no reactions occur during these stages [38], nor the reactor temperature, due to isothermal operating conditions; therefore, these stages were not considered in the simulation of the entire cyclic process. However, they were taken into account in the evaluation of the number of reactors needed to obtain continuous $\mathrm{H}_{2}$ production, as well as in the energy balance. 


\subsection{Process integration}

By operating the SE-SMR process in a network of fixed beds under the above-described conditions, it is possible to continuously produce a stream of high-purity $\mathrm{H}_{2}$. An interesting alternative is to feed the produced $\mathrm{H}_{2}$ to a fuel cell, as suggested by the recent environmental programs of the European Commission [39]. Since the stream of $\mathrm{H}_{2}$ from the SE-SMR process is available at high temperature $(973 \mathrm{~K})$, an SOFC could represent the optimal choice. In particular, in the outlet gas stream of the SE-SMR process, some unreacted $\mathrm{CH}_{4}$ is still present and, thus an internal reformer SOFC is suitable for this application. Moreover, due to the high pressure at which $\mathrm{H}_{2}$ is produced, a higher electrical efficiency for the SOFC is expected, as reported by Massardo and Lubelli [40] and by Isfahani and Sedaghat [41], who report SOFC efficiencies of up to $70 \%$ for operating pressures up to $3 \cdot 10^{6} \mathrm{~Pa}$. A schematic layout of the whole system is presented in Figure 2. The SE-SMR process has a number of energy demands, namely power demand of the vacuum pump, heat requirement of the calcination, pressurisation, depressurisation and purge stages and heat required to warm up the gas feed streams for each stage. In order to make this process self-sufficient from an energetic point of view, part of the produced $\mathrm{H}_{2}\left(\imath \cdot \mathrm{H}_{2} / \mathrm{CH}_{4}\right)$ is directly fed to an external burner, while the remaining part $\left((1-\imath) \cdot \mathrm{H}_{2} / \mathrm{CH}_{4}\right)$ is sent to the SOFC for power generation. Unreacted $\mathrm{H}_{2}$ from the fuel cell is also supplied to the burner. The partition ratio $\imath$ is calculated from an energy balance, so that the heat available from the burner and from the SOFC meet both the heat required by the SE-SMR process and that needed for SOFC internal reforming. Part of the SOFC power production is used to cover vacuum pump power demand, which represents the most energy-intensive step [37]. The net power production is the by-product of the present process, which can be used to environmentally meet energy demands of households or commercial buildings. Figure 2 also shows one of the main advantages of the SE-SMR, namely the inherent capture of $\mathrm{CO}_{2}$. Indeed, during the CAS a stream of $\mathrm{CO}_{2}$ and $\mathrm{H}_{2} \mathrm{O}$ is detected at the outlet of the fixed beds (red line) working under this stage. While part of this stream is directly re-fed to the same reactors working under the CAS, after adjusting the steamto- $\mathrm{CO}_{2}$ feed ratio, the remaining part is sent to a condenser together with the $\mathrm{CO}_{2} / \mathrm{H}_{2} \mathrm{O}$ gas stream at the outlet of the burner, obtaining a pure $\mathrm{CO}_{2}$ stream. 


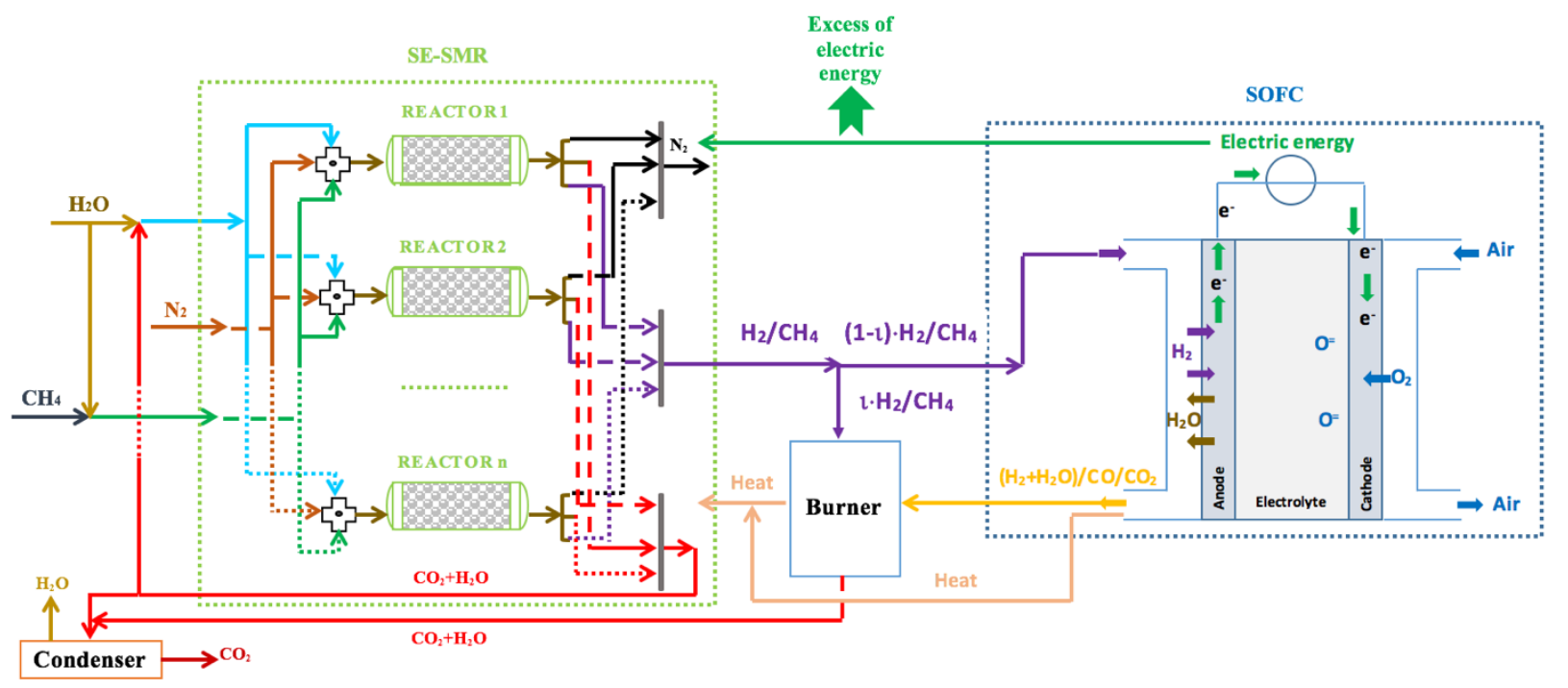

Figure 2 - Schematic layout of the SE-SMR process integrated with a SOFC.

\section{Mathematical model}

\subsection{Kinetic scheme}

The main chemical reactions involved in the SE-SMR are reported in Table 1. During the CS, the reactions involving $\mathrm{CH}_{4}$ promoted by the $\mathrm{Ni}$ catalyst include steam methane reforming (SMR), water gas shift (WGS), overall steam methane reforming (OSMR), dry reforming (DR), methane decomposition (MD) and carbon gasification by steam (CG-S) and by $\mathrm{CO}_{2}\left(\mathrm{CG}-\mathrm{CO}_{2}\right)$ [42]. However, as reported by Fernandez et al. [24], under typical SE-SMR operating conditions (high temperature and pressure), the reaction rates of $\mathrm{DR}, \mathrm{MD}, \mathrm{CG}-\mathrm{S}$ and $\mathrm{CG}-\mathrm{CO}_{2}$ (Boudouard reaction) are relatively low, thus these reactions are neglected for the sake of simplicity. These latter assumptions, taking into account the operating temperature considered in this work $(973 \mathrm{~K})$, are furthermore supported by the experimental findings of Iliuta et al. [42], who reports that in this case no carbon deposition on the catalyst surface occurs. The $\mathrm{CO}_{2}$ adsorption by the sorbent is described by the carbonation reaction (CR), while regeneration of the sorbents occurs via the reverse reaction of $\mathrm{CR}$, namely the calcination reaction (CALCR). It is noteworthy that in the operating conditions under study the equilibrium position of the reactions reported in Table 1 is shifted towards product formation, with the exception of WGS. The reaction mechanism proposed by $\mathrm{Xu}$ and Froment [43] was taken into account to describe SMR, WGS and OSMR, while those proposed by Rodriguez et al. [44] and Martinez et al. [45] were considered for the carbonation and calcination reactions, respectively. Table 2 reports the analytical expression of reaction rates, while kinetic data and equilibrium constant are shown in Table 3. $\mathrm{CO}_{2}$ partial pressure was expressed according to Baker [32]. For the sake of 
simplicity, the sorbent conversion degree was referred only to the carbonation reaction, thus it ranges between 0 , when only calcium oxide is present, and $X_{\max }$.

Table 1 - Kinetic scheme and relative heat (standard) of reactions.

\begin{tabular}{ccc}
\hline & Reaction & $\Delta \mathbf{H}^{\mathbf{0}}, \mathbf{k J} \cdot \mathbf{m o l}^{-\mathbf{1}}$ \\
\hline SMR & $\mathrm{CH}_{4}+\mathrm{H}_{2} \mathrm{O} \stackrel{\mathrm{Ni}}{\rightarrow} \mathrm{CO}+3 \mathrm{H}_{2}$ & 206.2 \\
WGS & $\mathrm{CO}+\mathrm{H}_{2} \mathrm{O} \stackrel{\mathrm{Ni}}{\leftrightarrow} \mathrm{CO}_{2}+\mathrm{H}_{2}$ & -41.5 \\
OSMR & $\mathrm{CH}_{4}+2 \mathrm{H}_{2} \mathrm{O} \stackrel{\mathrm{Ni}}{\rightarrow} \mathrm{CO}_{2}+4 \mathrm{H}_{2}$ & 164.9 \\
$\mathrm{CR}$ & $\mathrm{CaO}+\mathrm{CO}_{2} \rightarrow \mathrm{CaCO}_{3}$ & -178.8 \\
\hline
\end{tabular}

Table 2 - Reaction rates.

\begin{tabular}{|c|c|}
\hline Reaction & Reaction rate expression \\
\hline SMR & $R_{S M R}=\frac{k_{S M R}}{P_{H_{2}}^{2.5}}\left(P_{C H_{4}} P_{H_{2} O}-\frac{P_{H_{2}}^{3} P_{C O}}{K_{S M R}}\right)\left(\frac{1}{D E N^{2}}\right)$ \\
\hline WGS & $R_{W G S}=\frac{k_{W G S}}{P_{\mathrm{H}_{2}}}\left(P_{C O} P_{\mathrm{H}_{2} \mathrm{O}}-\frac{P_{\mathrm{H}_{2}} P_{C O_{2}}}{K_{W G S}}\right)\left(\frac{1}{D E N^{2}}\right)$ \\
\hline OSMR & $R_{O S M R}=\frac{k_{O S M R}}{P_{H_{2}}^{3.5}}\left(P_{C_{4}} P_{H_{2 O}}^{2}-\frac{P_{H_{2}}^{4} P_{C O_{2}}}{K_{O S M R}}\right)\left(\frac{1}{D E N^{2}}\right)$ \\
\hline $\mathrm{CR}$ & $R_{C R}=\frac{1}{M_{C a O}} k_{C R} \cdot\left(X_{\max }-X_{\text {Sorb }}\right) \cdot\left(v_{\mathrm{CO}_{2}}-v_{\mathrm{CO}_{2}, e q}\right)$ \\
\hline CALCR & $R_{C A L C R}=\frac{1}{M_{\mathrm{CaCO}_{3}}} k_{C A L C R} \cdot\left(\frac{X_{\text {sorb }}}{X_{\max }}\right)^{2 / 3} \cdot\left(C_{\mathrm{CO}_{2}, e q}-C_{\mathrm{CO}_{2}}\right)$ \\
\hline
\end{tabular}


Table 3 - Kinetic parameters and equilibrium constants.

\begin{tabular}{|c|c|}
\hline Expression & Unit \\
\hline$D E N=1+K_{C O} P_{C O}+K_{\mathrm{H}_{2}} P_{H_{2}}+K_{C_{4}} P_{C H_{4}}+K_{H_{2} O} \frac{P_{\mathrm{H}_{2} O}}{P_{\mathrm{H}_{2}}}$ & - \\
\hline$K_{S M R}=\exp \left(\frac{-26830}{T}+30.114\right)$ & bar $^{2}$ \\
\hline$K_{W G S}=\exp \left(\frac{4400}{T}-4.036\right)$ & - \\
\hline$K_{O S M R}=K_{S M R} \cdot K_{W G S}$ & bar $^{2}$ \\
\hline$k_{S M R}=\left(1.17 \cdot 10^{15}\right) \exp \left(\frac{-240100}{R_{g} T}\right)$ & mol.bar ${ }^{0.5} \cdot \mathrm{kg}^{-1} \cdot \mathrm{s}^{-1}$ \\
\hline$k_{W G S}=\left(5.43 \cdot 10^{5}\right) \exp \left(\frac{-67130}{R_{g} T}\right)$ & $\mathrm{mol} \cdot \mathrm{bar}^{-1} \cdot \mathrm{kg}^{-1} \cdot \mathrm{s}^{-1}$ \\
\hline$k_{\text {OSMR }}=\left(2.83 \cdot 10^{14}\right) \exp \left(\frac{-243900}{R_{g} T}\right)$ & $\mathrm{mol} \cdot \mathrm{bar}^{0.5} \cdot \mathrm{kg}^{-1} \cdot \mathrm{s}^{-1}$ \\
\hline$K_{C_{4}}=0.179 \exp \left[\frac{38280}{R_{g}}\left(\frac{1}{T}-\frac{1}{823}\right)\right]$ & bar $^{-1}$ \\
\hline$K_{\mathrm{H}_{2} \mathrm{O}}=0.4152 \exp \left[\frac{-88680}{R_{g}}\left(\frac{1}{T}-\frac{1}{823}\right)\right]$ & - \\
\hline$K_{H_{2}}=0.0296 \exp \left[\frac{82900}{R_{g}}\left(\frac{1}{T}-\frac{1}{648}\right)\right]$ & bar $^{-1}$ \\
\hline$K_{C O}=40.916 \exp \left[\frac{70650}{R_{g}}\left(\frac{1}{T}-\frac{1}{648}\right)\right]$ & bar $^{-1}$ \\
\hline$k_{C R}=0.35$ & $\mathrm{~s}^{-1}$ \\
\hline$k_{C A L C R}=252.015 \exp \left(\frac{-91700}{R_{g} T}\right)$ & $\mathrm{m}^{3} \cdot \mathrm{mol}^{-1} \cdot \mathrm{s}^{-1}$ \\
\hline
\end{tabular}

The rate of formation or consumption of $i$-species, $r_{i}$, is determined by summing the reaction rates of that species in all the reactions $R_{j}$ (see Table 1 ): 


$$
\begin{gathered}
r_{C H_{4}}=\left(-R_{S M R}-R_{O S M R}\right) \rho_{c a t} \\
r_{\mathrm{H}_{2} \mathrm{O}}=\left(-R_{S M R}-2 R_{O S M R}-R_{W G S}\right) \rho_{c a t} \\
r_{H_{2}}=\left(3 R_{S M R}+4 R_{O S M R}+R_{W G S}\right) \rho_{\text {cat }} \\
r_{C O_{2}}=\left(R_{O S M R}+R_{W G S}\right) \rho_{c a t}-R_{C R} \rho_{\text {sorb }}+R_{C A L C R} \rho_{\text {sorb }} \\
r_{C O}=\left(R_{S M R}-R_{W G S}\right) \rho_{c a t}
\end{gathered}
$$

In Eq. (1), $\rho_{c a t}$ and $\rho_{\text {sorb }}$ represent the density of catalyst and sorbent, respectively; these parameters were evaluated according to:

$$
\rho_{y}=\frac{m_{s} \omega_{y}}{\left(1-\varepsilon_{g}\right) V_{r}}
$$

where $y=$ sorb, cat. To carry out the simulation, a high-purity limestone ( $>98 \%$ calcium carbonate) [44] was considered as sorbent, while a conventional $\mathrm{Ni}(9 \%) / \gamma-\mathrm{Al}_{2} \mathrm{O}_{3}$ was considered as reforming catalyst [46].

\subsection{Governing equations}

To describe axial concentration profiles in the fixed bed reactor, a numerical 1D model was used. No radial concentration gradient is considered, according to [47], since $d_{r} / d_{p}>15$ [48]. Following the analysis proposed by Fernandez et al. [24], the influence of interphase concentration gradients was evaluated by means of the gas-solid mass transfer coefficient, $h_{m}$, calculated according to [49]:

$$
h_{m}=0.357 R e^{-0.359} S c^{-2 / 3}\left(\frac{G_{C S}}{\rho_{g} \varepsilon_{g}}\right)
$$

Considering the parameters used in this work, a value of $h_{m}$ of about $0.1 \mathrm{~m} \cdot \mathrm{s}^{-1}$ was estimated: thus, rapid gas-solid mass transfer can be assumed and the interphase concentration gradients can be safely neglected [50]. To take into account that the internal diffusion could be limiting for the overall reaction scheme, an effectiveness factor, $\sigma$, was considered for all reactions involved in the process: with the exception of the calcination reaction, the value of this latter assumed equal to 0.3 , as suggested by Solsvik and Jakobsen [51] for the SE-SMR process when large pellets (up to $7 \mathrm{~mm}$ ) are used. As reported by Fernandez et al. [20], the temperature is the main limiting parameter of the CALCR, thus possible intra-particle gradient concentration effects are negligible $(\sigma=1)$. In the model, 
it is assumed that the reactor works under isothermal conditions. To validate this assumption, the absence of both radial and axial temperature gradient, as well as the lack of intra-particle temperature gradient were verified. Mears criterion [52] was used to assess the effect of the interphase temperature gradient:

$$
N_{M e}=\frac{\left|\Delta H_{R j}\right| \cdot R_{o b s, j} \cdot\left(d_{p} / 2\right) \cdot E_{a, j}}{h_{f} \cdot R_{g} \cdot T^{2}}
$$

The above Mears number was evaluated with respect to both carbonation/reforming and calcination reactions. The gas-solid heat transfer coefficient was calculated according to [53]. For all inspected cases, a $N_{M e}<10^{-3}$ was estimated, thus radial temperature gradient can be neglected. Axial temperature gradient can be neglected too, as reported by [54], since the reactor length-to-diameter ratio is small $(<25)$ for the case under examination. The absence of intra-particle temperature gradient was verified by evaluating the temperature difference between the centre and the external surface of solid particle according to [55] and, at worst, it was less than $\sim 0.05 \mathrm{~K}$. As a consequence of the above, isothermal conditions can be safely assumed. The other assumptions of the developed models are: (a) ideal gas behaviour, (b) uniform particle size for solid material, (c) perfect mixing of the catalyst and sorbent and (d) negligible catalyst deactivation since $\mathrm{CaO}$ formed by calcination operated under vacuum condition is highly reactive, as stated above; moreover, after a slight decrease after the first carbonation/calcination cycle, the $\mathrm{CO}_{2}$ adsorption capacity of sorbent is almost constant over around 50 subsequent cycles, as reported by [56].

The model equations for both carbonation/reforming and calcination stages are reported in Table 4, with the corresponding boundary conditions. 
Table 4 - Carbonation/reforming and calcination stage mathematical model with corresponding boundary conditions.

Mass balance in the gas phase

$$
\varepsilon_{g} \frac{\partial C_{i}}{\partial t}+\frac{\partial\left(u C_{i}\right)}{\partial z}=\varepsilon_{g} \frac{\partial}{\partial z}\left(D_{a x} \frac{\partial C_{i}}{\partial z}\right)+\sigma\left(1-\varepsilon_{g}\right) r_{i}
$$

Mass balance in the solid phase for carbonation/reforming stage

$$
\frac{d X_{\text {sorb }}}{d t}=\sigma R_{C R} M_{C a O}
$$

Mass balance in the solid phase for calcination stage

$$
\frac{d X_{\text {sorb }}}{d t}=-\sigma R_{C A L C R} M_{\mathrm{CaCO}_{3}}
$$

Momentum equation

$$
\frac{d P}{d z}=\frac{150 \mu_{g}\left(1-\varepsilon_{g}\right)^{2}}{d_{p}{ }^{2} \varepsilon_{g}{ }^{3}} u+\frac{1.75\left(1-\varepsilon_{g}\right)}{d_{p} \varepsilon_{g}{ }^{3}} \frac{M_{g} P}{R_{g} T} u^{2}
$$

\section{Boundary conditions}

$$
\frac{\partial C_{i}(0, t)}{\partial z}=\frac{u}{\varepsilon_{g} D_{a x}}\left(C_{i}(0, t)-C_{i, i n}\right), \quad \frac{\partial C_{i}(L, t)}{\partial z}=0, \quad P(0, t)=P_{\text {in }}
$$

$\mathrm{CH}_{4}, \mathrm{H}_{2} \mathrm{O}, \mathrm{H}_{2}, \mathrm{CO}_{2}$ and $\mathrm{CO}$ are involved in the mass balance in the gas phase reported in Table 4 during the $\mathrm{CS}$, while only $\mathrm{CO}_{2}$ and $\mathrm{H}_{2} \mathrm{O}$ were taken into account during the CAS, considering that for steam no reactions occur over this step.

The mathematical model reported in Table 4 requires proper initial conditions. In particular, at the beginning of each CS in the cyclic sequence, as well as of each CAS, the spatial profiles of pressure and of all chemical species involved $\left(\mathrm{X}_{\text {sorb}}, \mathrm{CH}_{4}, \mathrm{H}_{2} \mathrm{O}, \mathrm{H}_{2}, \mathrm{CO}_{2}, \mathrm{CO}\right)$ need to be specified. SE-SMR in fixed beds is a periodically forced system with a period defined as $\tau_{\text {carlcalc }}=t_{\text {carb }}+t_{\text {calc }}$. The cyclic nature of SE-SMR is mathematically expressed by assuming as initial conditions of each step (CS and/or CAS) the last evaluated from the previous one. Assuming that the process starts with the carbonation stage, the first-run-only initial conditions for the CS of the very first cycle can be expressed as: 


$$
\begin{aligned}
& C_{C H_{4}}(z, 0)=C_{H_{2} O}(z, 0)=C_{H_{2}}(z, 0)=C_{C O_{2}}(z, 0)=C_{C O}(z, 0)=0 \\
& P(z, 0)=P_{C S} \\
& X_{\text {sorb }}(z, 0)=0
\end{aligned}
$$

while for all the subsequent CASs the initial conditions for solid conversion degree is assumed equal to the spatial profiles registered at the end of the previous CS, that is:

$$
X_{\text {sorb }}\left(z, t_{\text {carb }}+(k-1) \tau_{\text {car } / \text { calc }}\right)
$$

where $k=1,2, \ldots, n$ represents the cycle number and $t_{\text {carb }}+(k-1) \tau_{\text {car/calc }}$ the last time instant of the previous CS. Since after each CS there is a purge stage, $\mathrm{CO}_{2}$ and $\mathrm{H}_{2} \mathrm{O}$ spatial profiles are set equal to zero at the beginning of each CAS. After the first CS, at the beginning of the subsequent carbonation stage $X_{s o r b}$ is assumed to be equal to the spatial profiles registered at the end of the previous CAS, that is:

$$
X_{\text {sorb }}\left(z,(k-1) \tau_{\text {car } / \text { calc }}\right)
$$

where $k=2,3, \ldots, n$ represents the cycle number, while, since after each CAS there is a purge stage, $\mathrm{CH}_{4}, \mathrm{H}_{2} \mathrm{O}, \mathrm{H}_{2}, \mathrm{CO}$ and $\mathrm{CO}_{2}$ spatial profiles are set equal to zero at the beginning of each $\mathrm{CS}$. At the beginning of each carbonation and calcination stage, the pressure was set equal to $P_{C S}$ and $P_{C A S}$, respectively.

For the evaluation of temperature, pressure and composition dependencies of reaction enthalpies, transport coefficient and gas properties, state-of-the-art correlations and assumptions were adopted from Han et al. [57] and references therein. Operating conditions, reactor and catalyst data used in the simulations are reported in Table 5, while detailed boundary conditions used in the simulations are reported in Table 6. Reactor parameters $\left(L, d_{r}\right.$ and $\left.\varepsilon_{g}\right)$, as well as $G_{C S}$ and $\theta$ were taken from [24]. Under the operating conditions of the calcination stage, the value of gas inlet mass flux chosen, $G_{C A S}$, allows reaching a superficial velocity of about $0.5 \mathrm{~m} \cdot \mathrm{s}^{-1}$, which is close to the normal range of operation in industrial SMRs [58]. Furthermore, particle diameter, $d_{p}$, was selected from [43], maximum sorbent conversion, $X_{\max }$, was taken from [44], while $\omega_{\text {sorb }}$ and $\omega_{\text {carb }}$ were taken from [59], which proved that in typical SE-SMR operations about a $30 \%$ weight of Ni-based catalyst is 
sufficient. The mass of the solid in the reactor, $m_{s}$, was extrapolated from the data reported by [24], while the value of the steam-to- $\mathrm{CO}_{2}$ feed ratio during calcination stage, $\psi$, was chosen in accordance to Kavosh et al. [60], who reported that $\mathrm{CaO}$ produced with higher steam concentration $\left(y_{H 2 O} \sim 78 \%\right)$ during CAS is characterised by higher $\mathrm{CO}_{2}$ adsorption capacities.

The numerical model was solved using the commercial software package Comsol Multiphysics®. Reactor length, $L$, was discretised with 500 nodes and it was carefully checked that further refinements of the spatial discretisation did not produce any appreciable changes in the computed temperature and concentration profiles.

Table 5 - Parameters used in the simulations.

\begin{tabular}{|c|c|}
\hline Parameter & Value \\
\hline Temperature, $\mathrm{T}$ & $973 \mathrm{~K}$ \\
\hline Carbonation pressure, $\mathrm{P}_{\mathrm{CS}}$ & $3.5 \cdot 10^{6} \mathrm{~Pa}$ \\
\hline Calcination pressure, $\mathrm{P}_{\mathrm{CAS}}$ & $1013 \mathrm{~Pa}$ \\
\hline Reactor length, L & $7 \mathrm{~m}$ \\
\hline Reactor diameter, $\mathrm{d}_{\mathrm{r}}$ & $0.3 \mathrm{~m}$ \\
\hline Particle diameter, $d_{p}$ & $0.01 \mathrm{~m}$ \\
\hline Mass of solid in the reactor, $\mathrm{m}_{\mathrm{s}}$ & $415 \mathrm{~kg}$ \\
\hline Bed void fraction, $\varepsilon_{\mathrm{g}}$ & 0.5 \\
\hline Mass fraction of sorbent, $\omega_{\text {sorb }}$ & 0.33 \\
\hline Mass fraction of catalyst, $\omega_{\text {cat }}$ & 0.67 \\
\hline Steam-to-methane feed ratio during carbonation stage $\theta$ & 5 \\
\hline Steam-to- $\mathrm{CO}_{2}$ feed ratio during calcination stage, $\psi$ & 3 \\
\hline Mass flux of the gas phase in the carbonator, $\mathrm{G}_{\mathrm{CS}}$ & $3.5 \mathrm{~kg} \cdot \mathrm{m}^{-2} \cdot \mathrm{s}^{-1}$ \\
\hline Mass flux of the gas phase in the calciner, $\mathrm{G}_{\mathrm{CAS}}$ & $0.035 \mathrm{~kg} \cdot \mathrm{m}^{-2} \cdot \mathrm{s}^{-1}$ \\
\hline Maximum sorbent conversion, $\mathrm{X}_{\max }$ & 0.4 \\
\hline
\end{tabular}


Table 6 - Boundary conditions used in the simulations.

\begin{tabular}{ll|lc}
\hline Carbonation stage & \multicolumn{3}{c}{ Calcination stage } \\
\hline $\mathrm{T}$ & $973 \mathrm{~K}$ & $\mathrm{~T}$ & $973 \mathrm{~K}$ \\
$\mathrm{P}$ & $3.5 \cdot 10^{6} \mathrm{~Pa}$ & $\mathrm{P}$ & $1013 \mathrm{~Pa}$ \\
& & & \\
$\mathrm{C}_{\mathrm{CH} 4, \mathrm{in}}$ & $72 \mathrm{~mol} \cdot \mathrm{m}^{-3}$ & $\mathrm{C}_{\mathrm{CO} 2 \text {,in }}$ & $0.03 \mathrm{~mol} \cdot \mathrm{m}^{-3}$ \\
& & & \\
$\mathrm{C}_{\mathrm{H} 2 \mathrm{O}, \text { in }}$ & $360 \mathrm{~mol} \cdot \mathrm{m}^{-3}$ & $\mathrm{C}_{\mathrm{H} 2 \mathrm{O}, \text { in }}$ & $0.1 \mathrm{~mol} \cdot \mathrm{m}^{-3}$ \\
& & & \\
\hline
\end{tabular}

\section{Results and discussion}

The model presented above was first validated with literature data (Section 4.1), then numerical integration results for the first carbonation/reforming and calcination stages (Section 4.2) were reported. Subsequently, results for the cyclic process after several alternating carbonation/reforming and calcination cycles were presented and discussed (Section 4.3). Starting from these results, a possible approach to the operation of several reactors in parallel to obtain continuous $\mathrm{H}_{2}$ production was assessed (Section 4.4), and an energetic analysis of the fixed bed reactor network was performed (Section 4.5). Finally, an analysis of the performance of a SOFC directly fuelled with the produced $\mathrm{H}_{2}$ was carried out (Section 4.6).

\subsection{Model validation}

To validate the mathematical model, the literature data reported by Fernandez et al. [24] were considered. Importantly, since the chosen literature model has been developed for the carbonation/reforming stage operated in an autothermal fixed bed reactor, the model parameters were tailored and the energy balance was introduced to validate the model with the system described by Fernandez et al. [24]. In particular, the latter was introduced using the same approach proposed by the authors in their work [24]: 


$$
\begin{aligned}
& \quad\left[\left(1-\varepsilon_{g}\right) \rho_{s} c_{p s}+\varepsilon_{g} \rho_{g} c_{p g}\right] \frac{\partial T}{\partial t}+\frac{\partial\left(u \rho_{g} c_{p g} T\right)}{\partial z}=\varepsilon_{g} \frac{\partial}{\partial z}\left(\lambda_{a x} \frac{\partial T}{\partial z}\right)+\left(1-\varepsilon_{g}\right) \sigma\left[\rho_{c a t} \sum_{j} R_{j}\left(-\Delta H_{R_{j}}\right)+\right. \\
& \left.\rho_{\text {sorb }} R_{C R} \Delta H_{R_{C R}}\right]
\end{aligned}
$$

where $j=\mathrm{SMR}$, WGS and OSMR, $\rho_{s}$ is the density of the solid material $\left(\rho_{\text {cat }}+\rho_{\text {sorb }}\right)$, while the axial heat dispersion coefficient was evaluated according to [57], as well as temperature dependencies of reaction enthalpies. It is important to underline that the energy balance reported in Eq. (8) was used only to validate the mathematical model and was not taken into account in the process developed in this study. Figure 3 reports the molar fractions of gas products at the exit of the reactors as literature data (dots) and as predicted by the model (lines). The pre-breakthrough stage occurs until $t \sim 800 \mathrm{~s}:$ OSMR and CR take place and the outlet gaseous composition is close to the equilibrium values. The breakthrough stage starts at $t>800 \mathrm{~s}$, when $y_{\mathrm{CO} 2}$ begins to increases since sorbent is approaching its saturation. This stage lasts until $t<1500 \mathrm{~s}$, when the sorbent is fully saturated and only SMR and WGS occur. Of note, the model is able to describe both qualitatively and quantitatively the time trend of the literature data.

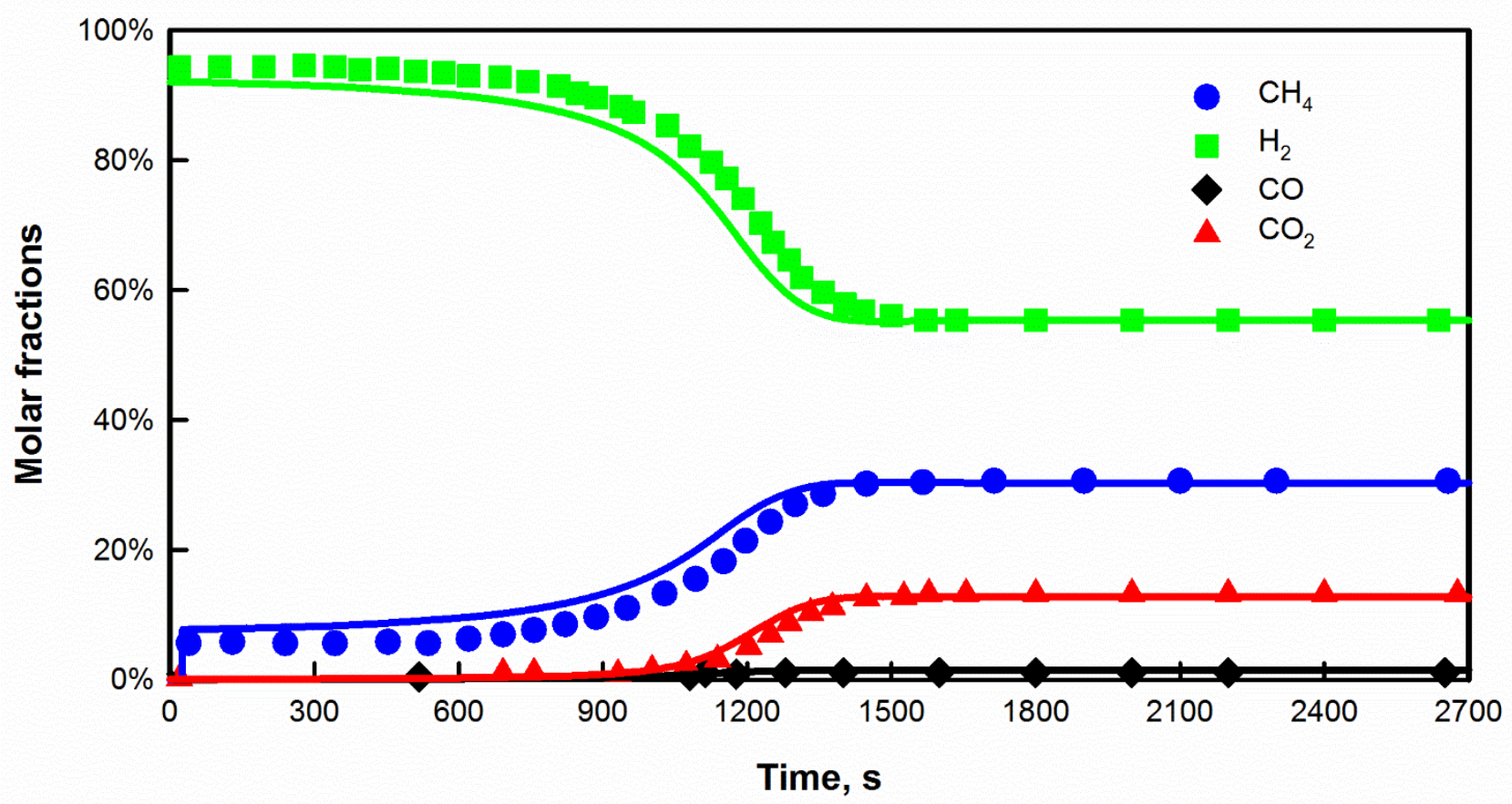

Figure 3 - Literature (dots, [24]) and simulated (lines) outlet gas molar fractions as function of time. 
Figure 4 presents gas molar fractions on a dry basis at the reactor exit (a) as function of time and spatial sorbent conversion degree profiles for four time points (b) during the first carbonation stage. Having analysed the results presented in Figure 4 (a), three distinct stages can be individuated: (1) pre-breakthrough $(t<500 \mathrm{~s})$, breakthrough $(500 \mathrm{~s}<\mathrm{t}<1500 \mathrm{~s})$ and post-breakthrough $(\mathrm{t}>$ $1500 \mathrm{~s})$. During the first stage, a high-purity- $\mathrm{H}_{2}$ gas stream is obtained $(\sim 95 \%)$, due to the presence of some unreacted methane as a result of the higher value of $P_{C S}$ [31], while $\mathrm{CO}_{2}$ and $\mathrm{CO}$ concentrations are practically zero. The former is completely adsorbed by the sorbent, while the latter is fully converted in the WGS reaction. In the second stage, $y_{H 2}$ dramatically decreases, reaching the value of 0.55 at the end of the breakthrough period, due to the decrease of sorbent adsorption capacity, as shown in Figure 4 (b) (see lines at $t=500 \mathrm{~s}$ and at $t=1000 \mathrm{~s}$ ). Concurrently, $y_{\mathrm{CH} 4}$ and $y_{\mathrm{CO} 2}$ rise to 0.20 and 0.12 , respectively, and also an increase in the CO molar fraction can be observed. This aligns with the observations reported by Li and Cai [26], who have shown that the decrease of carbonation reaction rate also reduces the SMR, WGS and OSMR extents. During the post-breakthrough period, the sorbent is fully saturated, as shown in Figure 4 (b) (at $t=1500$, the entire sorbent along the bed reached its maximum conversion, $X_{\max }$ ), thus only reforming and WGS reactions occur, and gas concentrations approached their equilibrium values.

The choice of carbonation time, $t_{c a r b}$, is very important. On the one hand, it is necessary to ensure the production of a high-purity- $\mathrm{H}_{2}$ gas stream, while on the other hand, high sorbent conversion should be obtained; a good compromise is to choose a time point within the breakthrough period. As a consequence of the above, a value of $1000 \mathrm{~s}$ was selected: at this time, the $\mathrm{H}_{2}$ content of outlet gas stream is still high $(\sim 75 \%)$, as shown in Figure 4 (a), and almost the entire sorbent in the bed has approached its maximum conversion degree, as highlighted in Figure 4 (b). 

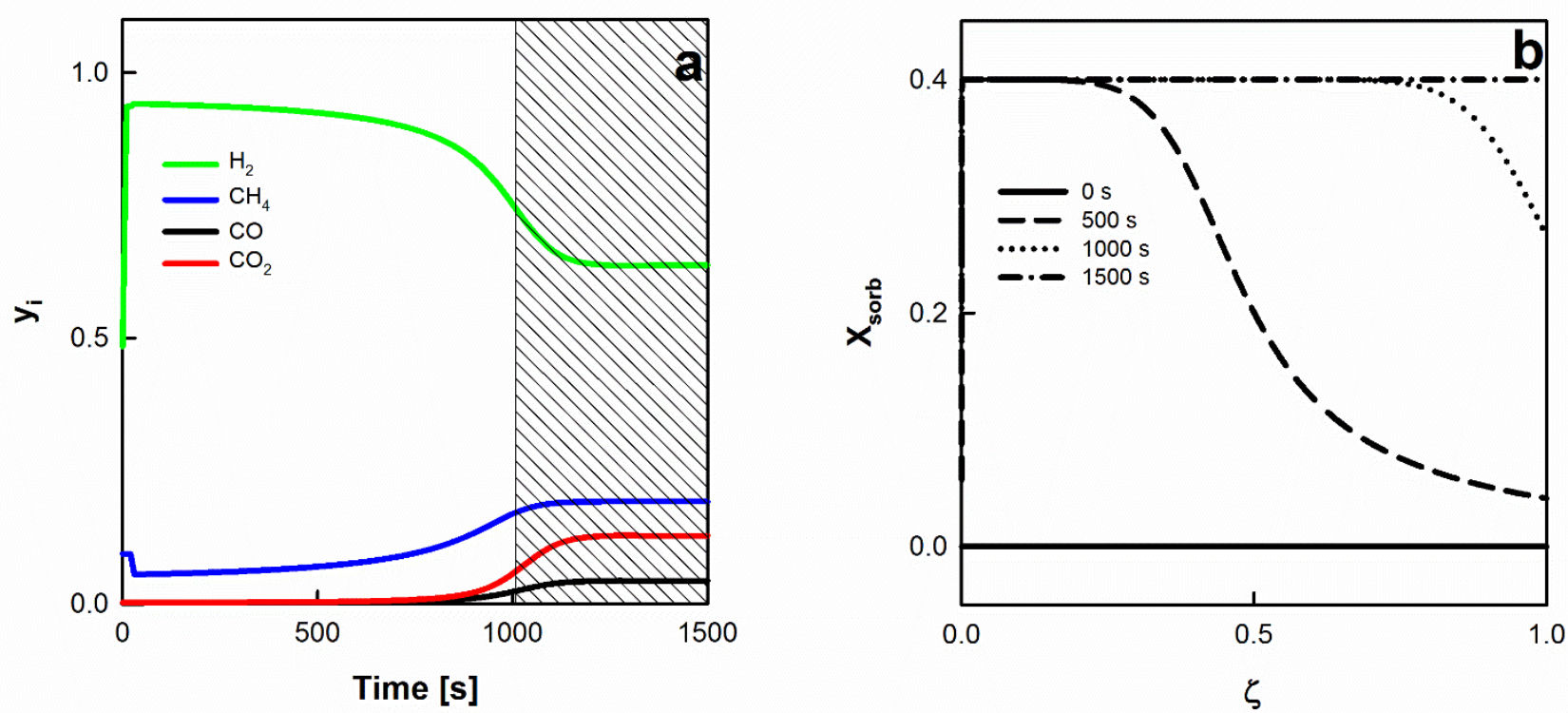

Figure 4 - Outlet gas molar fractions on dry basis (a) as function of the time and (b) sorbent conversion degree at different times during the first carbonation stage.

Starting from the solid conversion degree profiles at $t=1000 \mathrm{~s}$ shown in Figure 4 (b), the feed stream is switched and the pressure was reduced at $P_{C A S}$ to carry out the calcination stage. In order to choose the period for the CAS, Figure 5 reports the $\mathrm{CO}_{2}$ breakthrough curve (a) and spatial solid conversion degree profiles for five time points (b) during the first calcination stage. It is clear that it is necessary to carry out the CAS until the inlet $\mathrm{CO}_{2}$ concentration is detected at the exit of the reactor: this means that the calcination stage should end at $6000 \mathrm{~s}$, as shown in Figure 5 (a), i.e., $t_{c a c l}=5000 \mathrm{~s}$; after this period of time the entire sorbent is regenerated (see Figure 5 (b), $X_{\text {sorb }}$ is 0 everywhere). 

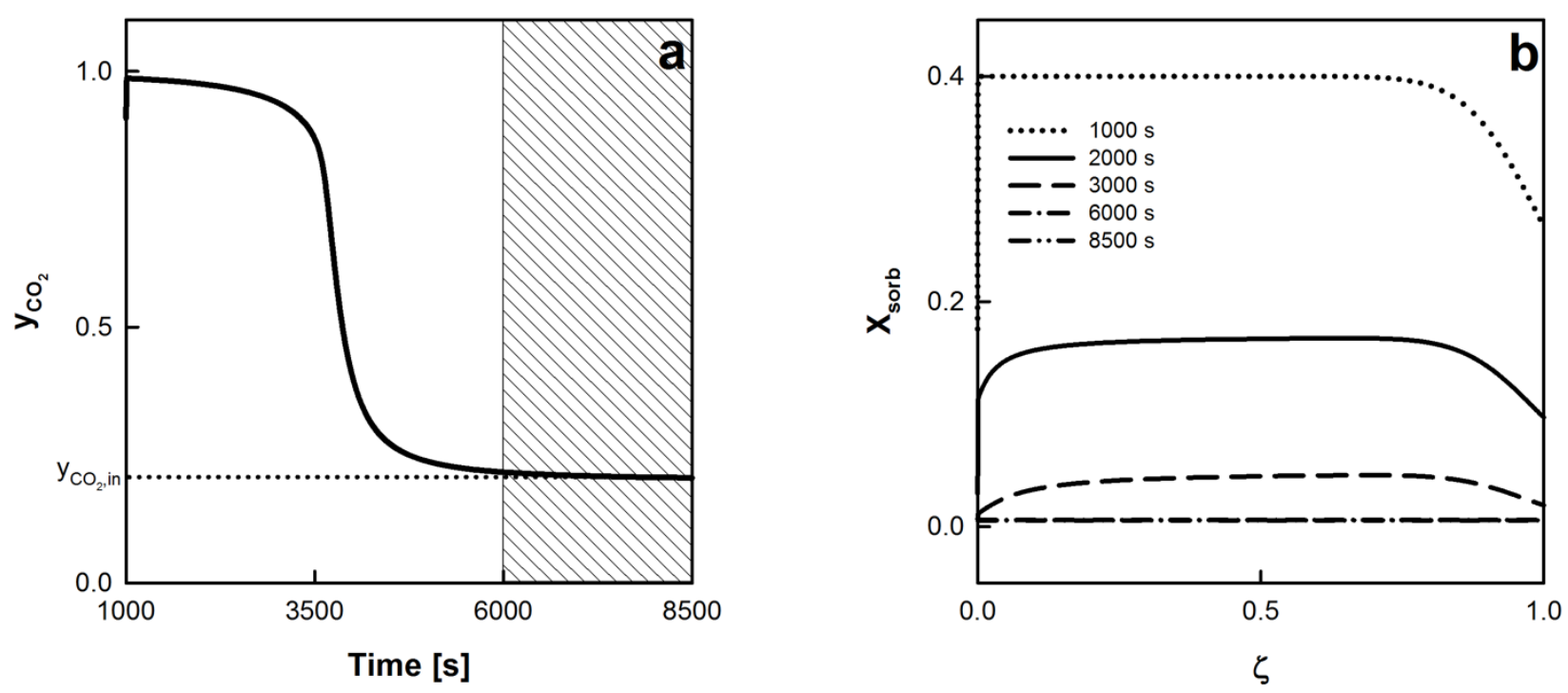

Figure 5 - Outlet $\mathrm{CO}_{2}$ molar fractions (a) as function of the time and (b) sorbent conversion degree at different times during the first calcination stage. The time horizon starts at the end of the previous CS (1000 s).

In short, it can be concluded that $6000 \mathrm{~s}$ is required to complete the first carbonation/reforming and calcination sequence. In these first two steps, the sorbent is first almost entirely saturated over the $\mathrm{CS}$, with consequent production of a high-purity- $\mathrm{H}_{2}$ gas stream ( $y_{\mathrm{H} 2}$ ranging from 0.95 at the beginning of CS to 0.75 at the end of the step), and then fully regenerated during the CAS.

\subsection{Cyclic carbonation/reforming and calcination sequence}

In this section, starting from the previously discussed CS and CAS, cyclic operation consisting of a sequence of carbonation/reforming and calcination stages is considered. Simulations are extended for more than 20 cycles in order to reach regime conditions in cyclic operations, which were met after 4-5 cycles (i.e., the difference between all the state variables at each spatial node at two successive cycles was below $10^{-6}$ ). Figure 6 reports outlet molar fractions of the gaseous species during the first 5 steps of cyclic operation of SE-SMR. The process starts with a CS (yellow zones), when a mixture of $\mathrm{CH}_{4}$ and $\mathrm{H}_{2} \mathrm{O}$ is fed to the reactor. Concentrations at the outlet of the bed over CS are characterised by the same trend described in Section 4.2. At $t=t_{c a r b}$, a mixture of steam and $\mathrm{CO}_{2}$ is fed to the reactor and a CAS (blue zones) takes place, up to the point when inlet $\mathrm{CO}_{2}$ concentration is detected at the outlet of the reactor, thus the subsequent CS starts. As a consequence, the feed is further switched to a mixture of $\mathrm{CH}_{4} / \mathrm{H}_{2} \mathrm{O}$ and, as shown in Figure 6, $y_{\mathrm{CO} 2}$ drops to zero. Again, after $t_{\text {carb }}$ seconds, a second CAS starts, and so on.

It is important to underline here that the main drawback of this process is the high-temperature valve system required to switch the feed stream, which represents the most challenging and expensive component [61]. 


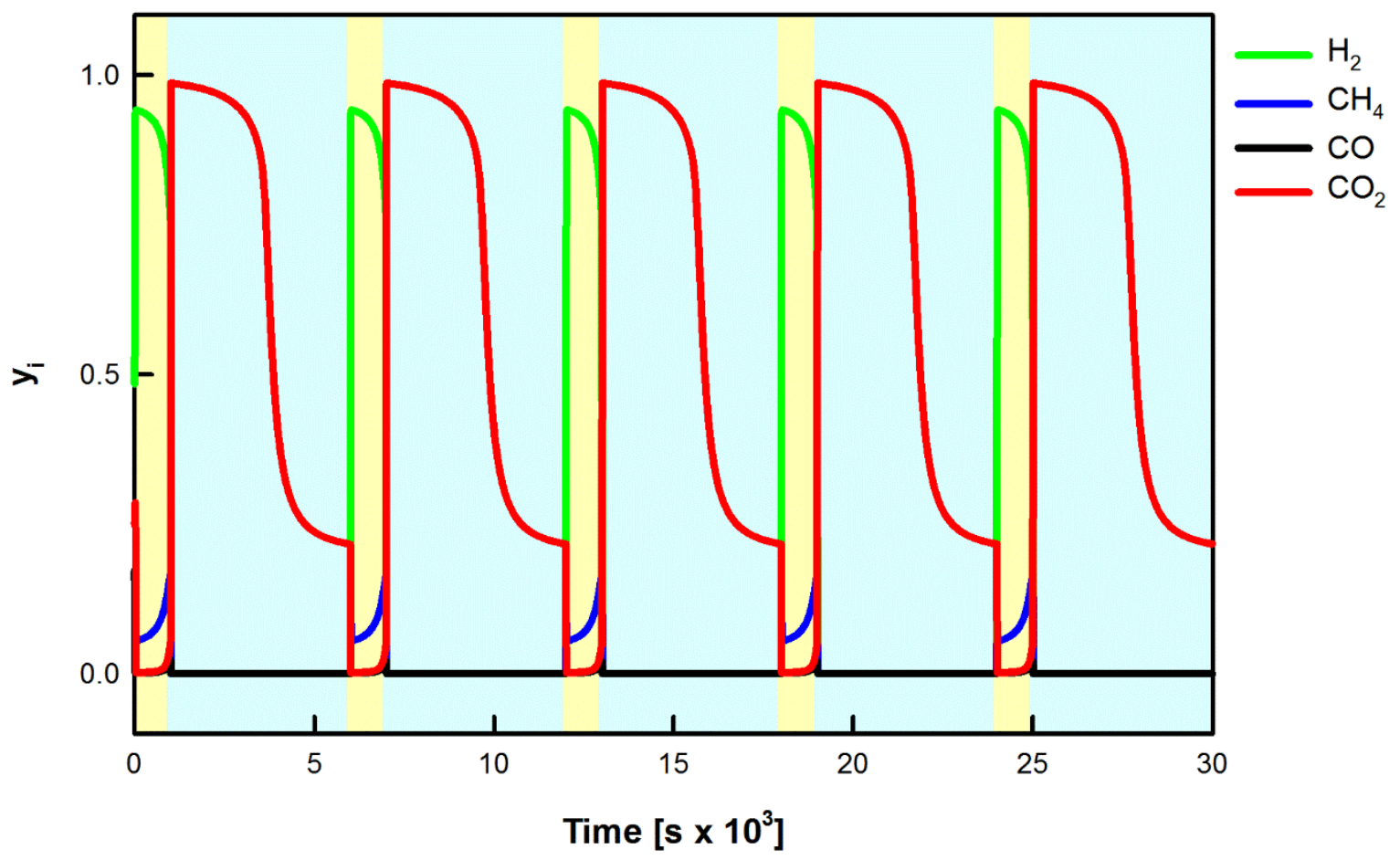

Figure 6 - Outlet gas molar fractions during multiple carbonation/reforming (in yellow)/calcination (in blue) cycles as function of the time.

\subsection{Fixed bed reactor network}

As highlighted in Section 4.3, a high-purity- $\mathrm{H}_{2}$ gas stream is produced only on CS, thus more than one reactor must be operated in a parallel configuration for continuous production of $\mathrm{H}_{2}$. To assess the minimum number of reactors needed, the whole cycle time has to be specified: as stated in Section 2, in addition to carbonation and calcination stages, also PPs, PR and D should be considered. It was assumed that both PP and PR were operated by feeding a $\mathrm{N}_{2}$ gas stream to the reactor, considering the same gas volumetric flow rate adopted during the carbonation stage. The periods of the purge $\left(t_{P S}\right)$ and of the pressurisation $\left(t_{P R}\right)$ stage were empirically evaluated: as suggested by Spallina et al. [62] $t_{P S}$ should be equal to $5 \%$ of the total period of the SE-SMR process ( $\left.\tau_{S E-S M R}\right)$; while considering the ratio between $P_{C S}$ and $P_{C A S}$ used in this work $t_{P R}$ can be equal to $10 \%$ of $\tau_{S E \text { - }}$ $S M R$, as stated by [38]. To estimate the period of the depressurisation stage, $t_{D}$, the relation reported by Chaudhari and Desai was used [63]:

$$
t_{D}=\frac{V_{r}}{Q_{D}} \ln \left(\frac{P_{C S}}{P_{C A S}}\right)
$$


where $Q_{D}$ represents the vacuum pumping volumetric flow during the depressurisation stage, which value was estimated equal to $0.01 \mathrm{~m}^{3} \cdot \mathrm{s}^{-1}$ (from the manufacturer's datasheets), selecting a proper device capable of achieving vacuum levels required [64].

From the above analysis, the following periods were obtained: $t_{P S}=400 \mathrm{~s}, t_{P R}=800 \mathrm{~s}, t_{D}=400 \mathrm{~s}$ and $\tau_{S E-S M R}=t_{c a r b}+t_{P S}+t_{D}+t_{c a l c}+t_{P S}+t_{P R}=8000 \mathrm{~s}$.

The required number of reactors $\left(N_{R}\right)$ needed to have a continuous $\mathrm{H}_{2}$ production is evaluated according to an empirical approach proposed by Spallina et al. [62], by ensuring that the maximum pressure drop $(\triangle P)$ in both the CS and CAS does not exceed the inlet pressure value by $15 \%$, since a high $\Delta P$ has the detrimental effect of increasing the capital and operating costs. The flow diagram for the general procedure adopted is reported in Figure 7:

- input data are the bed and solid material properties, the operating conditions (Table 5) and both the time period of the whole process $\left(\tau_{S E-S M R}\right)$ and of each stage $\left(\tau_{c a r b}, \tau_{P S}, \tau_{D}, \tau_{c a l c}, \tau_{P R}\right)$.

- First, it is necessary to assess the minimum number of reactors required to ensure that at least one reactor always works in the $\mathrm{H}_{2}$ production stage, i.e. in the carbonation stage; this number $\left(N_{R, \min }\right)$ is calculated by rounding the ratio between $\tau_{S E-S M R}$ and $\tau_{\text {carb }}$ to the nearest integer greater than or equal to it.

- Starting from the calculated value of $N_{R, \min }$, the pressure drop $(\Delta P)$ in both the CS and CAS is evaluated via the Ergun equation [65]:

$$
\frac{\Delta P}{L}=150 \frac{\mu_{g}}{d_{p}{ }^{2}} \frac{\left(1-\varepsilon_{g}\right)^{2}}{\varepsilon_{g}{ }^{3}} u+1.75 \frac{\rho_{g}}{d_{p}} \frac{\left(1-\varepsilon_{g}\right)}{\varepsilon_{g}{ }^{3}} u^{2}
$$

where the gas superficial velocity $u$ is estimated as [61]:

$u=\frac{\dot{m}}{\rho_{g} \phi N_{R}\left(\pi d_{r}^{2} / 4\right)}$

and the average number of reactors working in the considered stage, $\phi$, is assessed according to the current number of reactors by inspecting the time sequence of the operations of the reactor network; 
- The pressure conditions are checked: if $\triangle P$ in the CS or CAS is lower than $15 \%$ of the corresponding inlet pressure value, the procedure is stopped and $N_{R}$ is set to the value previously assessed; otherwise, the number of reactor is increased by one unit and pressure drop is re-calculated; the procedure is repeated until the pressure criterion is met.

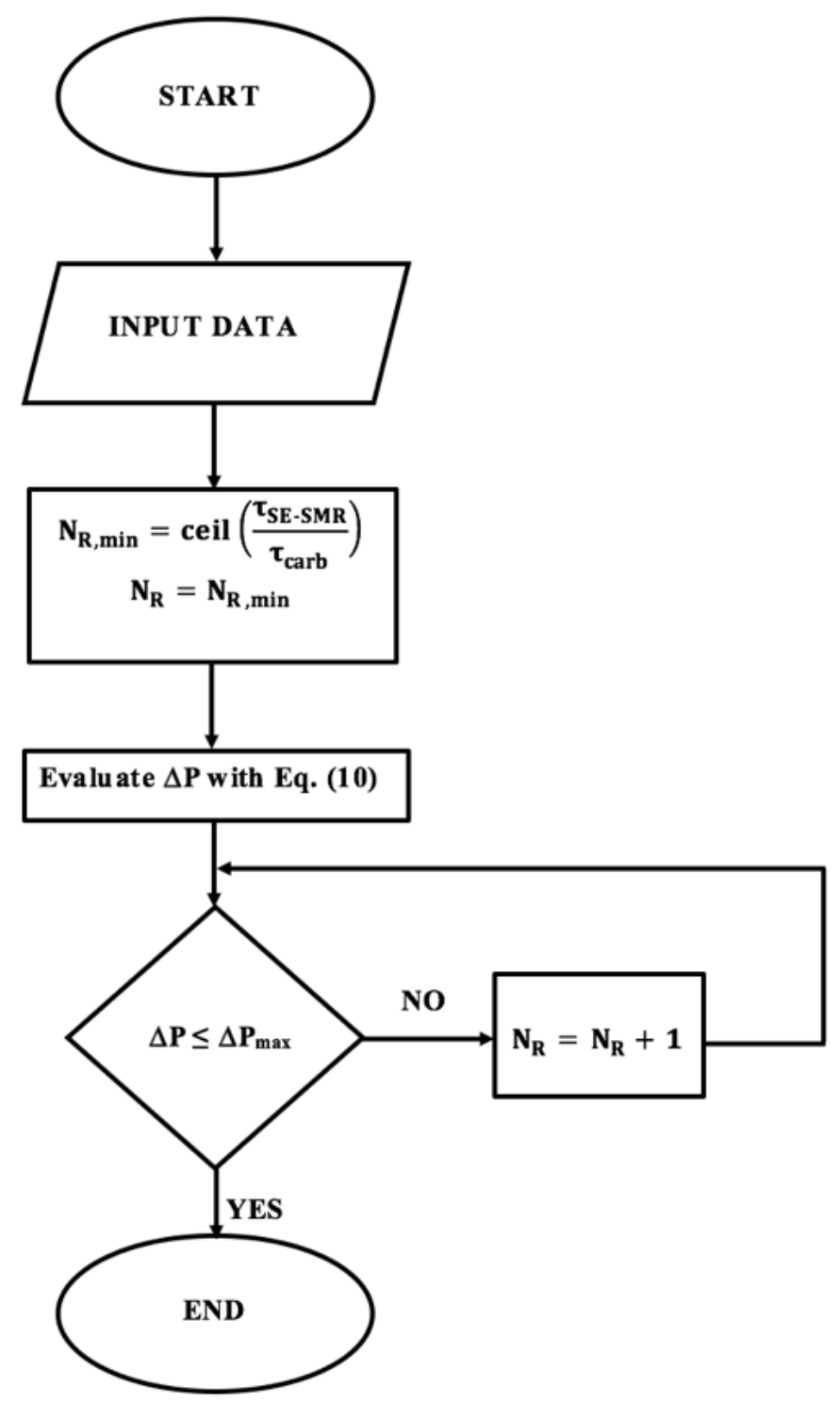

Figure 7 - Simplified flow diagram of general procedure to evaluate the number of reactors.

Following the above method, in the case under evaluation the minimum number of reactors required to guarantee that at least one reactor is always in the CS is $\tau_{S E-S M R} / t_{c a r b}=8000 / 1000=8$. In this case $\phi$ in the carbonation and calcination stage is $1 / N_{R}=0.12$ and $5 / N_{R}=0.62$, respectively (see Figure 7). According to Eq. (10), $\Delta P$ is $2 \%$ and $4 \%$ of the inlet pressure value in the CS and CAS, 
respectively. Since the selected $N_{R}$ matches the condition proposed by Spallina et al. [61], eight reactors in parallel were chosen to carry out the proposed process.

In Figure 8 the time sequence of the operations of the reactor network is reported: for each reactor, the yellow zone represents the carbonation stage, the orange zone the purge stage, the green zone the depressurisation stage, the blue zone the calcination stage and the purple zone the pressurisation stage. At the beginning of the operations, all the sorbent contained in the 8 reactors is characterised by maximum $\mathrm{CO}_{2}$ adsorption capacity; at $t=0$, the mixture of $\mathrm{CH}_{4}$ and $\mathrm{H}_{2} \mathrm{O}$ is fed only to reactor 1 , which is in CS and will be in this stage until $t=t_{\text {carb }}$; at this point, the feed of reactor 1 is switched to $\mathrm{N}_{2}$ for the subsequent purge stage, while the mixture of methane and steam feed is started to reactor 2, that will be in CS from this time up to $t=2 t_{c a r b}$. According to this approach, after every $t_{\text {carb }}$ a mixture of $\mathrm{CH}_{4} / \mathrm{H}_{2} \mathrm{O}$ is fed to a new reactor $j\left(j=1, \ldots, N_{R}\right)$, which will be the only one working in CS, while the $N_{R}-j$ reactors above $j$ follow the above-discussed step sequence CS-PS-D-CAS-PSPR. When $j=N_{R}=8$ also the last reactor is started to CS, and will be in this stage up to $t=t_{S E-S M R}$; at this time reactor 1 is ready to restart a new carbonation/reforming cycle, and from this time on, the above-described sequence of operations will be reiterated with a time period of $\tau_{\text {SE-SMR }}$.

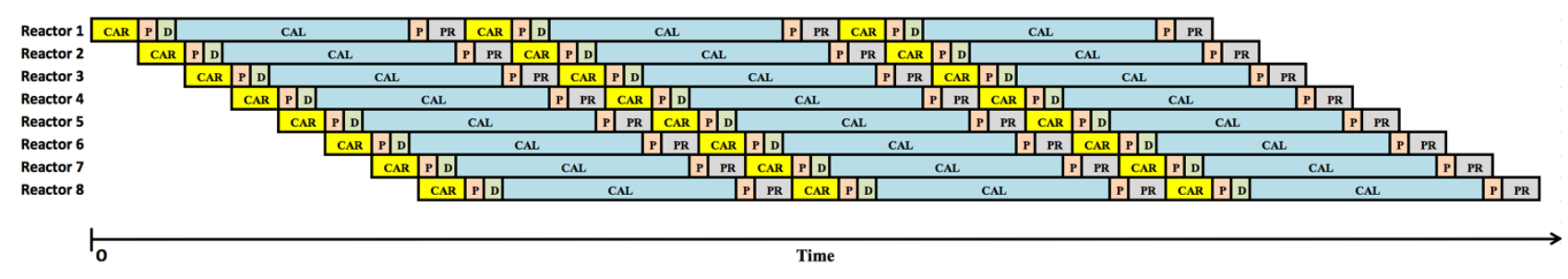

Figure 8 - Time sequence of the operation of the reactor network (carbonation $(C A R)$ in yellow, purge $(P)$ in orange, depressurisation $(D)$ in green, calcination $(C A L)$ in blue and pressurisation $(P R)$ in purple).

Figure 9 shows gas molar fractions at the outlet of the reactor network as a function of the time: as above-assessed, this stream is composed of the gas stream leaving the reactor $m\left(m=1, \ldots, N_{R}\right)$ currently working in CS, with $m=m+1$ each $t_{c a r b}$. It is noteworthy that by employing 8 fixed beds in parallel, a continuous $\mathrm{H}_{2}$ stream with an average value of $y_{H 2}=0.92$ can be obtained. 


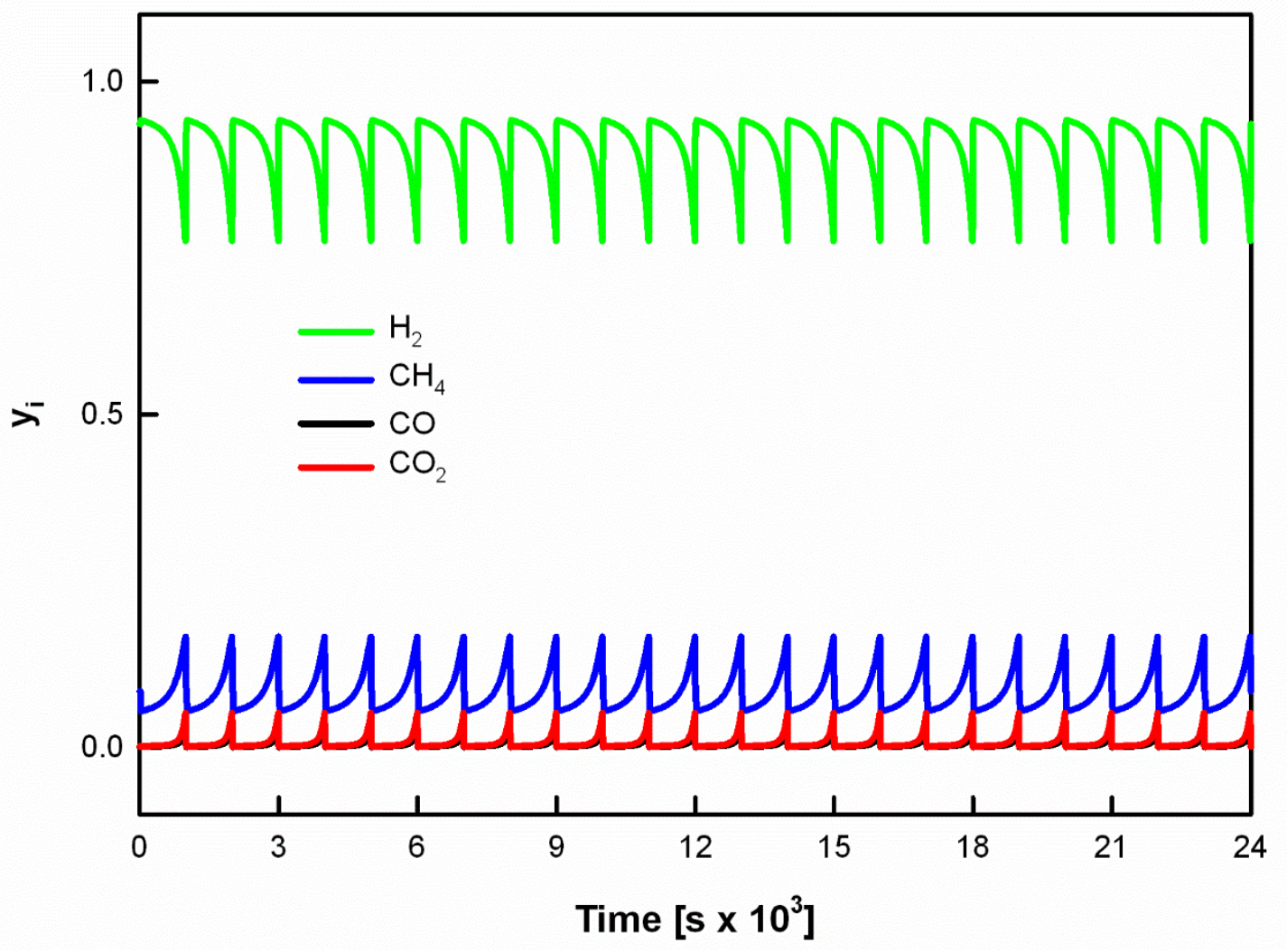

Figure 9 - Gas molar fractions at the outlet of reactor network as a function of the time.

In order to evaluate the performance of the proposed reactor network, Figure 10 reports methane conversion, $X_{C H 4}$, (a), $\mathrm{H}_{2}$ yield, $\eta_{H_{2}}$, (b) and selectivity, $S_{H_{2}}$, (c) as functions of time. Methane conversion is close to $80 \%$. As the CS of the reactor currently working in the carbonation stage approaches its end, $\mathrm{X}_{\mathrm{CH} 4}$ decreases to about 55\%, as is apparent in Figure 10 (a). $\mathrm{H}_{2}$ yield (Figure 10 (b)) and selectivity (Figure 10 (c)) are significantly higher than corresponding values found in the literature in alternative $\mathrm{H}_{2}$ production applications. The former ranges between about 2 and $3 \mathrm{~mol}_{\mathrm{H} 2} \cdot \mathrm{mol}_{\mathrm{CH} 4}{ }^{-1}$, more than four times the value of about $0.5 \mathrm{~mol}_{\mathrm{H} 2} \cdot \mathrm{mol}_{\mathrm{CH} 4}{ }^{-1}$ assessed by Diglio et al. [7]. The latter ranges between about $80 \%$ and $94 \%$, while Halabi et al. [66] calculated a value of about $73 \%$. The applications presented by Diglio et al. [7] and Halabi et al. [66] are characterised by poorer $\mathrm{H}_{2}$ yield and selectivity because their outlet gas stream is syngas. In this case, a further gas post-processing unit is required to obtain $\eta_{H 2}$ and $S_{H 2}$ closer to those reached in the SE-SMR process proposed in this paper, with increased costs and system complexity. 

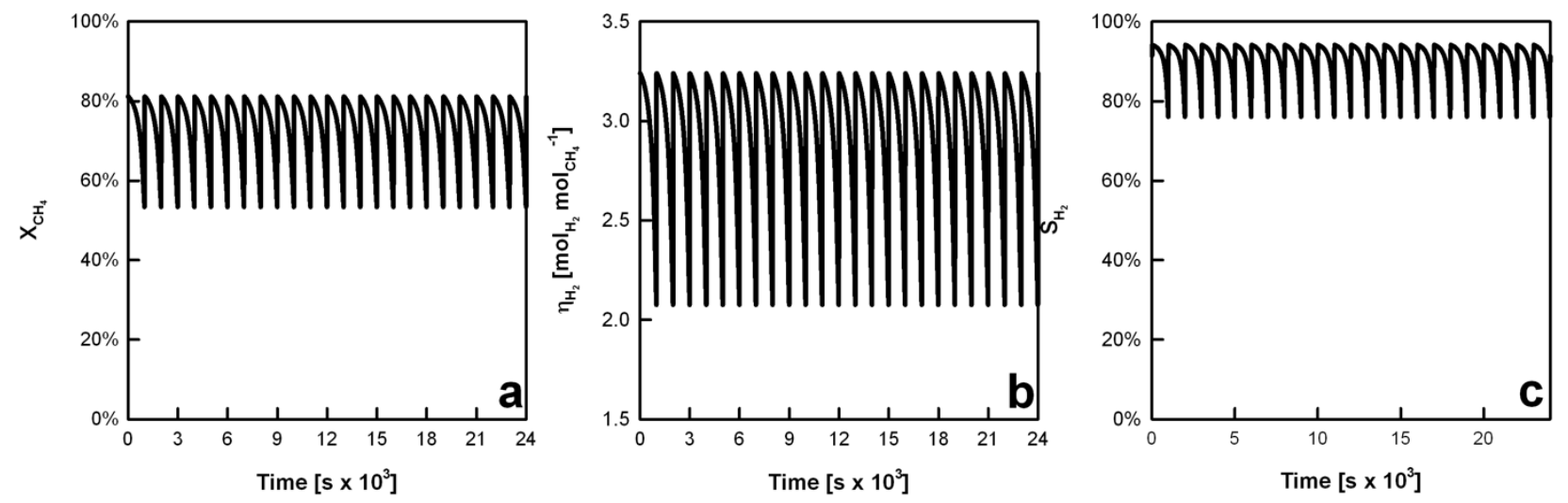

Figure 10 - Methane conversion (a), $\mathrm{H}_{2}$ yield (b) and selectivity (c) at the outlet of reactor network as function of time.

\subsection{Thermodynamic performance analysis}

In order to carry out the proposed process, not only is external heating to operate each stage under isothermal conditions and to heat up the feed gas streams to the reactor temperature required, but also an external electric power generation device to meet vacuum pump power demand is needed. As originally proposed by Ryden and Lyngfelt [67], part of the $\mathrm{H}_{2}$ produced by the reforming process could be used as fuel for this purpose, avoiding the $\mathrm{CO}_{2}$ emissions due to the burning of conventional fossil fuel.

In this case, further useful indices to evaluate the performance of the SE-SMR process are the $\mathrm{H}_{2}$-equivalent yield, $\eta_{H 2 \text {,equivalent, }}$ which represents the amount of $\mathrm{H}_{2}$ remaining per mole of methane supplied if all external heat and power demands were met by using the produced $\mathrm{H}_{2}$, and reformer efficiency, $\gamma_{\text {ref }}[14,67]$ :

$$
\begin{gathered}
\eta_{H_{2}, \text { equivalent }}=\eta_{\mathrm{H}_{2}}-\frac{H_{\text {ext }}}{L H V_{\mathrm{H}_{2}}} \\
\gamma_{\text {ref }}=\eta_{\mathrm{H}_{2}, \text { equivalent }} \frac{L H V_{H_{2}}}{L H V_{C H_{4}}}
\end{gathered}
$$

$L H V_{H 2}$ and $L H V_{C H 4}$ are $241.8 \cdot 10^{3} \mathrm{~J} \cdot \mathrm{mol}^{-1}$ and $802.3 \cdot 10^{3} \mathrm{~J} \cdot \mathrm{mol}^{-1}$, respectively [68], while $H_{e x t}$ is the external heat and power demand of the process per mole of $\mathrm{CH}_{4} \mathrm{fed}$, and it was evaluated according to: 


$$
H_{e x t}=\frac{\dot{Q}_{C A S}+2 Q_{P S}+\dot{Q}_{P R}+\dot{Q}_{D}+\dot{Q}_{f}+E_{D}}{\dot{n}_{C H_{4}, \text { in }}}
$$

where $\dot{Q}_{C A S}, \dot{Q}_{P S}, \dot{Q}_{P R}$ and $\dot{Q}_{D}$ are the external heat required to carry out, under isothermal conditions, calcination, purge, pressurisation and depressurisation stages, respectively; $\dot{Q}_{f}$ is the external heat needed to warm feed gas streams up to operating temperature $(973 \mathrm{~K}) ; E_{D}$ is the electric power demand of the vacuum pump; and $\dot{n}_{\mathrm{CH}_{4}, \text { in }}$ is the inlet $\mathrm{CH}_{4}$ molar flow rate. All heat demands considered in the process are schematically presented Figure 11.

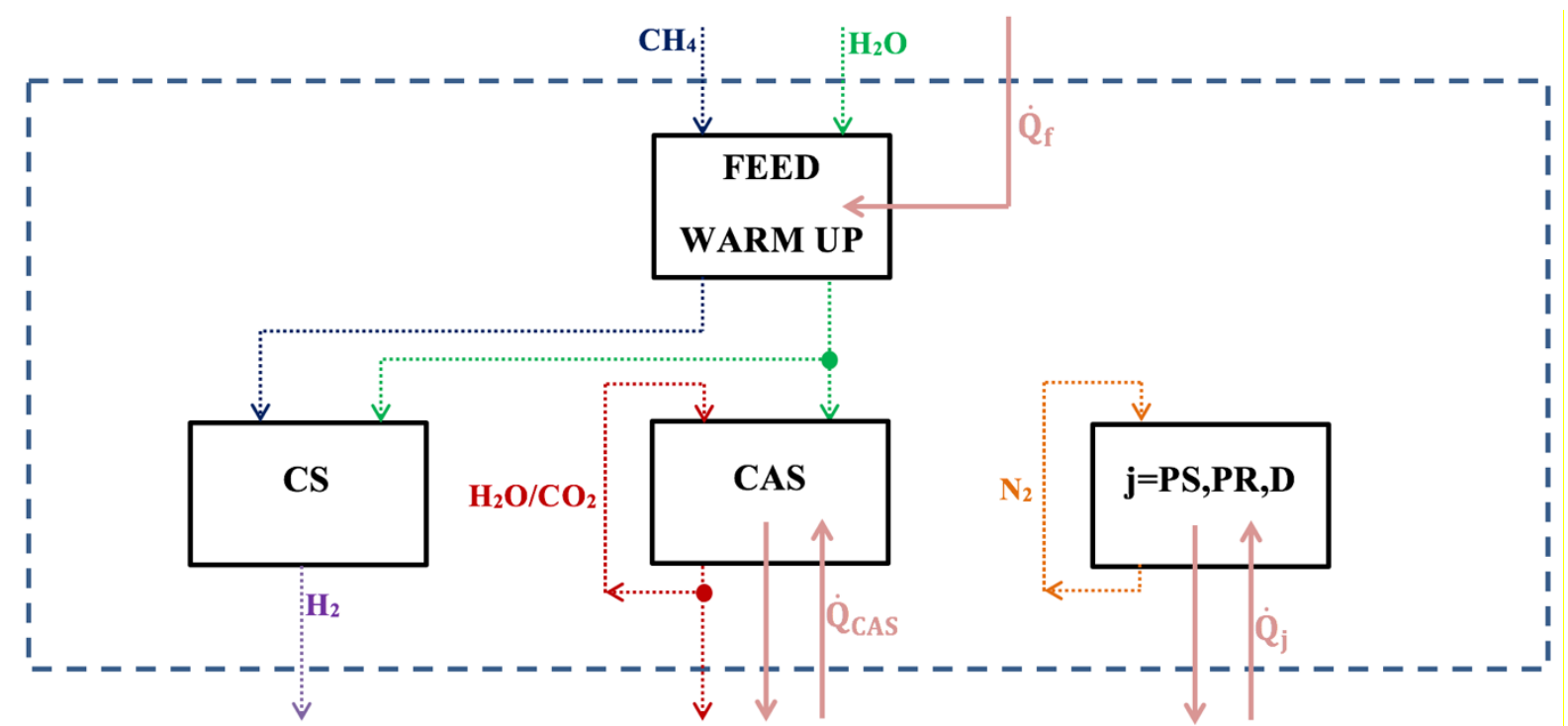

Figure 11 - Heat demands in the SE-SMR process.

In particular, to evaluate $\dot{Q}_{C A S}$ the following energy balance was written [69]:

$$
\begin{aligned}
& Q_{C A S, \text { in }} \cdot\left[C_{\mathrm{H}_{2} \mathrm{O}, \text { in }} \cdot h_{\mathrm{H}_{2} \mathrm{O}, \text { in }}+C_{\mathrm{CO}_{2}, \text { in }} \cdot h_{\mathrm{CO}_{2}, \text { in }}\right]-Q_{C A S, \text { out }} \cdot\left[C_{\mathrm{H}_{2} \mathrm{O}, \text { out }} \cdot h_{\mathrm{H}_{2} \mathrm{O}, \mathrm{out}}+C_{\mathrm{CO}_{2}, \mathrm{out}} \cdot\right. \\
& \left.h_{\mathrm{CO}_{2}, \mathrm{out}}\right]+V_{r} \cdot \rho_{\text {sorb }} \cdot\left(1-\varepsilon_{g}\right) \cdot \Delta H_{R_{C A L C R}} \cdot R_{C A L C R}=N_{C A S} \cdot \frac{1}{\varphi} \cdot \frac{1}{L} \int_{0}^{L} \dot{Q}_{C A S} d L
\end{aligned}
$$

where $\varphi$ is an effectiveness factor which takes into account that only half the heat generated by the external heating is available, as a consequence of limited heat transfer between external heating and reactor wall [70] and $N_{C A S}$ is the number of reactors working in CAS at the considered time. 
During the purge, pressurisation and depressurisation stages no reactions occur, thus the required thermal power is due only to the heat transfer between reactor wall and ambient, and was evaluated according to Shafeeyan et al. [54]:

$$
\dot{Q}_{j}=\frac{1}{\varphi} \cdot N_{j} \cdot V_{r} \cdot \frac{1}{L} \int_{0}^{L} \frac{4 h_{w}}{\varepsilon_{g} d_{r}}\left(T-T_{w}\right) d L
$$

where $j=\mathrm{PS}, \mathrm{PR}$ and $\mathrm{D}, N_{j}$ is the number of the reactor working in the stage $j$ at the considered time, $T$ is the reactor temperature $(973 \mathrm{~K})$ and $T_{w}$ is the temperature of the reactor wall, which was estimated by means of the wall energy balance [54]:

$$
\rho_{w} c_{p, w} \frac{\partial T_{w}}{\partial t}=h_{w} \cdot A_{w} \cdot\left(T-T_{w}\right)+U \cdot A_{a} \cdot\left(T_{a m b}-T_{w}\right)
$$

The external overall heat transfer coefficient reported in Eq. (17), $U$, was estimated through the following correlation [71]:

$$
\begin{aligned}
& \frac{1}{U}=\frac{1}{h_{w}}+\frac{d_{r}}{\lambda_{w}} \ln \left(\frac{d_{r}+s_{S}}{d_{r}}\right)+\frac{d_{r}}{\left(d_{r}+s_{S}\right) \cdot h_{e x t}} \\
& \frac{h_{e x t} L}{\lambda_{a m b}}=0.68+\frac{0.67 R a^{1 / 4}}{\left[1+(0.492 / P r)^{9 / 12}\right]^{4 / 9}} \\
& R a=\frac{g \beta_{b}\left(T_{w}-T_{a m b}\right) L^{3}}{v_{v} \cdot \alpha_{a}}
\end{aligned}
$$

The values of $v_{v}$ and $\alpha_{a}$ were evaluated at the film temperature, i.e., $\left(T_{w}+T_{a m b}\right) / 2$. The resistance of the reactor wall to the radial heat transfer was taken into account in the overall heat transfer coefficient $U$ [54]. Eqs. (17-20) were used to check if the reactor vessel surface, $A_{r}$, is large enough for the heat flux required by calcination stage to be transferred from the burner. In particular, replacing the last term on the right-hand-side of Eq. (17) with the heat supplied during the calcination stage and evaluating the external overall heat transfer coefficient, $U$, by taking into account the 
temperature of combustion products of the burner as $T_{a m b}$, a heat exchange surface area, $A_{E H}$, much lower than $A_{r}$, is required $\left(\sim 0.2 \mathrm{~A}_{r}\right)$.

The proposed layout is composed of 4 inlet gas streams: methane fed during CS (stream\#1), steam supplied during both CS and CAS (stream\#2), $\mathrm{N}_{2}$ fed during both PS and PR (stream\#3) and $\mathrm{CO}_{2}$ fed during CAS (stream\#4). While stream\#3 and stream\#4 (this latter after adjusting the value of $\psi$ ) are recirculated and directly fed to the reactors working in PS and/or PR and in CAS, respectively, stream\#1 and stream\#2 need to be heated up from ambient temperature to the operating temperature $T=973 \mathrm{~K}$. In order to evaluate the thermal power required for this purpose, $\dot{Q}_{f}$, the following equation was used:

$$
\dot{Q}_{f}=\left[Q_{C H_{4}, i n} \cdot \rho_{C_{4}} \cdot c_{p, C H_{4}}+Q_{H_{2} O, i n} \cdot \rho_{H_{2} O} \cdot c_{p, H_{2} O}\right] \cdot\left(T-T_{a m b}\right)
$$

The power demand, $E_{d}$, of the vacuum pump was estimated (from the manufacturer's datasheets) as $1.5 \mathrm{~kW}_{\mathrm{el}}$, considering the maximum power required by the pump. The parameters used in the simulations to calculate required thermal power are reported in Table 7, considering steel as wall material, while all gas-phase physical correlations can be found in [68]. Table 8 reports spatial and time-averaged value of thermal power required in each stage and time-averaged values of power required to warm up feed gas streams. According to the results assessed by Diglio et al. [72] $\dot{Q}_{f}$ is the highest thermal power, while, as expected, CAS is the most energy-demanding SE-SMR stage due to the endothermic calcination reaction.

To prove that the total energy demands can be entirely supplied by the system itself, the results of the thermodynamic analysis are shown in Figure 12 as time functions of $\mathrm{H}_{2}$ yield, $\eta_{H 2}$, and equivalent $\mathrm{H}_{2}$ yield, $\eta_{H 2 \text {,equivalent }}$ (a) and reformer efficiency (b) at the outlet of the reactor network: the average value $\eta_{\mathrm{H} 2}$ is about $2.9 \mathrm{~mol}_{\mathrm{H} 2} \cdot \mathrm{mol}_{\mathrm{CH} 4}{ }^{-1}$, while that of $\eta_{\mathrm{H} 2 \text {, equivalent }}$ is about $2.5 \mathrm{~mol}_{\mathrm{H} 2} \cdot \mathrm{mol}_{\mathrm{CH} 4}{ }^{-}$ 1. Thus, it is noteworthy that by using part of the $\mathrm{H}_{2}$ produced by the reforming process (about $0.4 \mathrm{~mol}_{\mathrm{H} 2} \cdot \mathrm{mol}_{\mathrm{CH} 4}{ }^{-1}$ ) to generate heat and power from an external source, it is possible to fully cover the energy demands of the SE-SMR system, reaching energy self-sufficiency. As a consequence, the proposed layout is characterised by near-zero- $\mathrm{CO}_{2}$ emissions. The average reformer efficiency value is about $80 \%$, close to those of similar applications [14].

The heat required by the endothermic calcination stage is the main drawback of SE-SMR and still limits its adoption. The above results help to overcome this issue by evaluating an operational strategy which makes the process self-sufficient on an energy point of view and can be used by system 
designers in order to promote this technology in industrial processes using $\mathrm{H}_{2}$ as fuel [73], such as methanol and ammonia synthesis. Moreover, integration with fuel cell is one of the most suitable applications of the proposed system, resulting in an environmentally friendly power generation technology, as shown below.

Table 7 - Parameters used for energy balance.

\begin{tabular}{cc}
\hline Parameter & Value \\
\hline Ambient temperature, $\mathrm{T}_{\mathrm{amb}}$ & $298 \mathrm{~K}$ \\
Inlet volumetric flow rate of methane, $\mathrm{Q}_{\mathrm{CH} 4, \mathrm{in}}$ & $0.38 \mathrm{~m} \cdot \mathrm{s}^{-1}$ \\
Inlet volumetric flow rate of steam, $\mathrm{Q}_{\mathrm{H} 2 \mathrm{O}, \mathrm{in}}$ & $0.34 \mathrm{~m}^{3} \cdot \mathrm{s}^{-1}$ \\
Reactor wall thickness, $\mathrm{s}_{\mathrm{s}}$ & $0.3 \mathrm{~m}$ \\
Reactor wall thermal conductivity, $\lambda_{\mathrm{w}}$ & $45 \mathrm{~W} \cdot \mathrm{m}^{-1} \cdot \mathrm{K}^{-1}$ \\
Reactor wall heat capacity, $\mathrm{c}_{\mathrm{p}, \mathrm{w}}$ & $460 \mathrm{~J} \cdot \mathrm{kg}^{-1} \cdot \mathrm{K}^{-1}$ \\
Reactor wall density, $\rho_{\mathrm{w}}$ & $7850 \mathrm{~kg}^{-1} \cdot \mathrm{m}^{-3}$ \\
\hline
\end{tabular}

Table 8 - Average thermal power.

\begin{tabular}{cl}
\hline Thermal power & \multicolumn{1}{c}{ Value } \\
\hline Calcination stage, $\dot{Q}_{C A S}$ & $1000 \mathrm{~W}$ \\
Purge stage, $\dot{Q}_{P S}$ & $200 \mathrm{~W}$ \\
Pressurisation stage, $\dot{Q}_{P R}$ & $500 \mathrm{~W}$ \\
Depressurisation stage, $\dot{Q}_{D}$ & $150 \mathrm{~W}$ \\
Thermal power required to warm up feed gas streams, $\dot{Q}_{f}$ & $1000 \cdot 10^{3} \mathrm{~W}$ \\
\hline
\end{tabular}



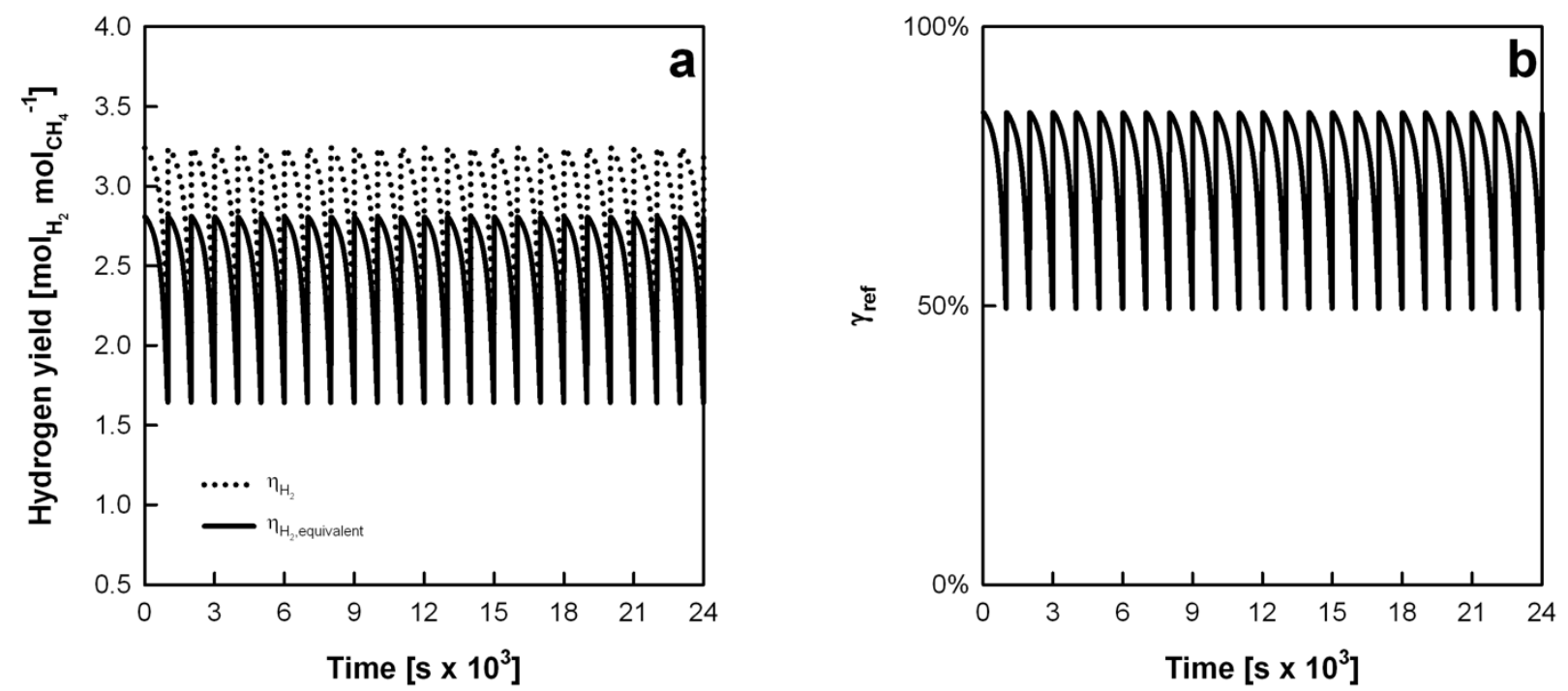

Figure $12-\mathrm{H}_{2}$ yield, as dotted line, and equivalent $\mathrm{H}_{2}$ yield, as solid line (a), and reformer efficiency (b) at the outlet of reactor network as function of time.

\subsection{SOFC performance evaluation}

In the following the performance of the system consisting of the integration of the proposed SE-SMR process and a solid oxide fuel cell is assessed. It is worth noting that albeit detailed mathematical models of SOFC are available in the literature (e.g., [74]), in order to be correctly used they all need an exhaustive description of SOFC operations [74], which is far beyond the scope of this paper, which is just a preliminary evaluation of the energetic potential of an integrated SE-SMRSOFC system. As a consequence, the performance of SOFCs were assessed through the simple approach suggested by [75].

SOFCs are classified into two types, namely the internal and external reformer SOFC, according to the place where reforming reactions occur. Since in the $\mathrm{H}_{2}$ gas stream of the SE-SMR process a small amount of unreacted $\mathrm{CH}_{4}$ is still present, as above-disclosed, in this case the internal reformer SOFC represents a suitable choice.

As shown in Figure 2, the system is heat-led. This means that an external burner fed with both a portion of the produced $\mathrm{H}_{2}$ and unreacted $\mathrm{H}_{2}$ from the SOFC is used to meet heat demands of the SE-SMR process and of SOFC internal reforming, taking also into account the heat available from the SOFC. The remaining $\mathrm{H}_{2}$ is fed to the SOFC for power production which, net of the vacuum pump power demands, represents the output of the system.

The SOFC voltage was evaluated by means of the Nerst equation [75]: 


$$
V_{S O F C}=\gamma_{i n v}\left[\frac{-\Delta G_{f}^{0}}{2 F}+\frac{R_{g} T}{4 F} \ln \left(\frac{P}{P_{0}}\right)\right]-V_{\text {loss }}
$$

where $\Delta G_{f}^{0}$ is the change in molar Gibbs free energy of formation of the overall reaction that happens in the considered fuel cell $\left(2 \mathrm{H}_{2}+\mathrm{O}_{2} \rightarrow 2 \mathrm{H}_{2} \mathrm{O}\right)$ at standard pressure $\left(-237.2 \cdot 10^{3} \mathrm{~J} \cdot \mathrm{mol}^{-1}\right)[75], P$ is the operating pressure of the fuel cell $\left(3.5 \cdot 10^{6} \mathrm{~Pa}\right.$ in this case), $P_{0}$ is the standard pressure, $F$ is the Faraday constant, $V_{\text {loss }}$ represents the fuel cell voltage losses and includes the activation-related loss, the ohmic loss and the concentration loss [76]. The voltage loss depends on the operating conditions, such as temperature, pressure, gas concentrations, current density, etc. Its estimation requires a detailed mathematical model of the SOFC, which is beyond the scope of the present work. For the sake of simplicity, $V_{\text {loss }}$ was empirically evaluated equal to $0.2 \mathrm{~V}$ by means of the data reported by Akkaya [77], considering the operating pressure and temperature utilised in the present work. Moreover, $\gamma_{i n v}$ represents the efficiency of the commercial inverter needed to convert direct current from the SOFC to alternating current and was set equal to $98 \%$ [41].

The alternating current power, $E_{S O F C}$, electrical efficiency, $\gamma_{e l, S O F C}$, at the outlet of the SOFC, and net power production of the SOFC, $E_{n e t}$, were calculated through the following correlations [78]:

$$
\begin{aligned}
& E_{S O F C}=V_{S O F C} \cdot f_{u} \cdot(1-\imath) \cdot\left(\dot{n}_{H_{2}, S E-S M R}+3 \dot{n}_{C H_{4}, S E-S M R}\right) \cdot 2 F \\
& \gamma_{e l, S O F C}=\frac{E_{S O F C}}{(1-\iota) \cdot\left(\dot{n}_{H_{2}, S E-S M R} \cdot L H V_{H_{2}}+3 \dot{n}_{C H_{4}, S E-S M R} \cdot L H V_{C H_{4}}\right)} \\
& E_{\text {net }}=E_{S O F C}-E_{D}
\end{aligned}
$$

where $\dot{n}_{H_{2}, S E-S M R}$ is the molar flow rate of $\mathrm{H}_{2}$ at the outlet of the SE-SMR fixed-bed reactor network; $3 \dot{n}_{C H_{4}, S E-S M R}$ represents the molar flow rate of $\mathrm{H}_{2}$ produced by internal reforming, considering that the SMR reaction occurs; $f_{u}$ is the SOFC fuel utilisation, which accounts for the fuel not utilised by the fuel cell (its value was assumed equal to 0.95 [75]), $\imath$ is the $\mathrm{H}_{2}$ partition ratio between the external burner and the fuel cell. It is important to highlight here that, for the sake of simplicity, it was assumed 
that all methane in the feed gas stream is converted in the internal reforming process, thus $f_{u}$ is referred only to the hydrogen as fuel.

To evaluate the value of $\imath$ the following energy balance was written:

$$
\dot{Q}_{S E-S M R}+\dot{Q}_{\text {ref }}-\dot{Q}_{S O F C}-\dot{Q}_{\text {burner }}=0
$$

where $\dot{Q}_{S E-S M R}$ is the heat demand of the SE-SMR process and its value is about $1.08 \mathrm{MW}_{\mathrm{th}}$; this latter was evaluated by means of:

$$
\dot{Q}_{S E-S M R}=\int_{0}^{\tau_{S E-S M R}}\left(\dot{Q}_{C A S}+2 \dot{Q}_{P S}+\dot{Q}_{P R}+\dot{Q}_{D}+\dot{Q}_{f}\right) d t
$$

$\dot{Q}_{\text {SOFC }}$ is the heat generated by SOFC and was assessed as follows:

$$
\dot{Q}_{S O F C}=\left[\frac{\left(1-\gamma_{e l, S O F C}\right)}{\gamma_{e l, S O F C}} \cdot \frac{E_{S O F C}}{\gamma_{\text {inv }}}\right]
$$

The thermal power produced by the burner, $\dot{Q}_{\text {burner }}$, is:

$$
\begin{aligned}
& \dot{Q}_{\text {burner }}=\left(1-f_{u}\right) \cdot(1-\imath) \cdot\left(\dot{n}_{H_{2}, S E-S M R}+3 \dot{n}_{C H_{4}, S E-S M R}\right) L H V_{H_{2}}+\iota \cdot\left(L H V_{H_{2}} \cdot\right. \\
& \left.\dot{n}_{H_{2}, S E-S M R}+L H V_{C H_{4}} \cdot \dot{n}_{C H_{4}, S E-S M R}\right)
\end{aligned}
$$

where the first term on the right-hand side of Eq. (29) represents the heat generated by burning unreacted $\mathrm{H}_{2}$ from the fuel cell, while the second term is the heat obtained by the combustion of the gas stream from the SE-SMR process.

The heat demand for SOFC internal reforming, $\dot{Q}_{r e f}$, was evaluated according to:

$$
\dot{Q}_{r e f}=(1-\imath) \cdot 3 \dot{n}_{C H_{4}, S E-S M R} \cdot \Delta H_{R_{S M R}}
$$


From the above analysis, a partition ratio, 1 , of 0.45 , an $E_{n e t}$ of about $950 \mathrm{~kW}_{\mathrm{el}}$ and a $\gamma_{e l, S O F C}$ of about $70 \%$ were estimated. Notably, the value of the SOFC electrical efficiency is very close to those reported in the literature for SOFCs working at operating pressures similar to $P_{C S}$ that was used in this analysis [41]. The net efficiency of the entire system (i.e., the ratio between the net power production of the SOFC and the chemical energy of the methane at the inlet of the SE-SMR section) is about $51 \%$. This represents an outstanding result for two main reasons. On the one hand, the net efficiency of the entire system is only slightly less than that of other similar applications, in which the power production is increased by the integration of the SOFC with a gas turbine [79]. On the other hand, it is remarkable that this high efficiency also encompasses $\mathrm{CO}_{2}$ capture.

It is important to stress here that $\mathrm{H}_{2} \mathrm{O}$ at the outlet of the SOFC could be used in the SE-SMR process, decreasing not only the steam consumption, but also the $\dot{Q}_{f}$.

Since the burner outlet gas mixture of $\mathrm{H}_{2} \mathrm{O}$ and $\mathrm{CO}_{2}$ is sent to a condenser (see Figure 2), the only source of $\mathrm{CO}_{2}$ emissions in the proposed system is the small amount of $\mathrm{CO}_{2}$ that could be present in the outlet gas stream during the purge stages and at the outlet of the SOFC if also SMR happens simultaneously with OSMR.

Thus, it can be inferred that the net power production of the suggested layout $\left(\sim 950 \mathrm{~kW}_{\mathrm{el}}\right)$ could be used to meet the energy demand of commercial buildings, district heating of residential houses or industrial processes, with near-zero- $\mathrm{CO}_{2}$ emissions.

\section{Conclusion}

In this paper a SE-SMR process carried out in a network of fixed bed reactors was numerically investigated by means of a one-dimensional mathematical model validated with literature data. The proposed process was operated under isothermal conditions $(973 \mathrm{~K})$ and the equilibrium between the carbonation and calcination stages was shifted via a pressure swing cycle: the reforming and $\mathrm{CO}_{2}$ adsorption stage was accomplished at high pressure $\left(3.5 \cdot 10^{6} \mathrm{~Pa}\right)$, in order to reduce reactor size and the cost of $\mathrm{H}_{2}$ production, while the sorbent regeneration was operated under vacuum (1013 Pa), with two beneficial effects, i.e., lower operating temperature and consequent mitigation of sorbent reactivity decay. The numerical simulations revealed that the choice of the time period for each stage should be carefully done. In particular, the time period of the carbonation stage was taken equal to $1000 \mathrm{~s}$, in order to have both high-purity $\mathrm{H}_{2}$ production and high sorbent conversion, while the duration of the calcination stage was set equal to $5000 \mathrm{~s}$, in order to fully regenerate the sorbent. This resulted in a time period for the whole cycle of $8000 \mathrm{~s}$ involving a carbonation-purge- 
depressurisation-calcination-purge-pressurisation sequence which repeated in a cyclical manner. Under the above conditions, it was assessed that at least 8 reactors in parallel are required to continuously produce a stream with an average $\mathrm{H}_{2}$ purity of $92 \%$. To carry out the proposed process a number of energy demands have to be met, namely: heat required by the endothermic calcination reaction; thermal energy necessary to heat up feed gas streams and to operate pressurisation, depressurisation and purge stages under isothermal conditions; and power required by the vacuum pump. By means of an energetic analysis it was demonstrated that it is possible to use part of the produced $\mathrm{H}_{2}$ to supply all heat and power demands, making the process energy self-sufficient: in this case $\mathrm{H}_{2}$ yield decreases from $2.9 \mathrm{~mol}_{\mathrm{H} 2} \cdot \mathrm{mol}_{\mathrm{CH} 4}{ }^{-1}$ to $2.5 \mathrm{~mol}_{\mathrm{H} 2} \cdot \mathrm{mol}_{\mathrm{CH} 4}{ }^{-1}$. It is important to underline that these results are strictly related to the system under investigation, for which the assumption of isothermal conditions was carefully checked. Clearly, if different oxygen carrier, reactor sizes or operating conditions are taken into account, the heat management strategy should be carefully checked by assessing the dynamic behaviour of the system.

Assessment of the integration between the proposed SE-SMR and an internal reforming SOFC was carried out. Part of the produced $\mathrm{H}_{2}$ was directly fed to an external burner, together with unreacted $\mathrm{H}_{2}$ from the SOFC, in order to fully cover heat demand of both the SE-SMR process and SOFC internal reforming. Also, the heat available from the SOFC was used to decrease the heat required by the entire system. The remaining portion of produced $\mathrm{H}_{2}$ was sent to the SOFC, reaching a power production of $\sim 950 \mathrm{~kW}_{\mathrm{el}}$, net of power demand of the vacuum pump, and a SOFC electrical efficiency of $\sim 70 \%$. The net efficiency of the entire system was about $51 \%$. Thus, the analysed layout could be used as a near-zero- $\mathrm{CO}_{2}$ emissions stationary power generation system for commercial/industrial buildings or district heating of residential houses.

\section{References}

[1] P. Zakkour, G. Cook, Rodamap for industry: high-purity $\mathrm{CO}_{2}$ source, Carbon Counts Company Ltd, London, 2010.

[2] É. Fontana, E. Mancusi, A.A. Ulson de Souza, S.M.A. Guelli Ulson de Souza, Flow regimes for liquid water transport in a tapered flow channel of proton exchange membrane fuel cells (PEMFCs), J. Power Sources. 234 (2013) 260-271. doi:10.1016/j.jpowsour.2013.01.171.

[3] G. Marbán, T. Valdés-Solís, Towards the hydrogen economy?, Int. J. Hydrogen Energy. 32 (2007) 1625-1637. doi:10.1016/j.ijhydene.2006.12.017.

[4] G. Pantoleontos, E.S. Kikkinides, M.C. Georgiadis, A heterogeneous dynamic model for the simulation and optimisation of the steam methane reforming reactor, Int. J. Hydrogen Energy. 37 (2012) 16346-16358. doi:10.1016/j.ijhydene.2012.02.125. 
[5] C.D. Bohn, C.R. Müller, J.P. Cleeton, A.N. Hayhurst, J.F. Davidson, S.A. Scott, et al., Production of Very Pure Hydrogen with Simultaneous Capture of Carbon Dioxide using the Redox Reactions of Iron Oxides in Packed Beds, Ind. Eng. Chem. Res. 47 (2008) 76237630. doi:10.1021/ie800335j.

[6] G. Diglio, P. Bareschino, R. Solimene, E. Mancusi, F. Pepe, P. Salatino, Numerical simulation of hydrogen production by chemical looping reforming in a dual fluidized bed reactor, Powder Technol. 316 (2017) 614-627. doi:10.1016/j.powtec.2016.12.051.

[7] G. Diglio, P. Bareschino, E. Mancusi, F. Pepe, Simulation of Hydrogen Production through Chemical Looping Reforming Process in a Packed-Bed Reactor, Chem. Eng. Res. Des. 105 (2015) 137-151. doi:10.1016/j.cherd.2015.11.013.

[8] V. Spallina, B. Marinello, F. Gallucci, M.C. Romano, M. Van Sint Annaland, Chemical looping reforming in packed-bed reactors: Modelling, experimental validation and largescale reactor design, Fuel Process. Technol. 156 (2017) 156-170.

doi:10.1016/j.fuproc.2016.10.014.

[9] D.P. Hanak, E.J. Anthony, V. Manovic, A review of developments in pilot plant testing and modelling of calcium looping process for $\mathrm{CO}_{2}$ capture from power generation systems, Energy Environ. Sci. 8 (2015) 2199-2249. doi:10.1039/c5ee01228g.

[10] M. Broda, V. Manovic, Q. Imtiaz, A.M. Kierzkowska, E.J. Anthony, C.R. Müller, Highpurity hydrogen via the sorption-enhanced steam methane reforming reaction over a synthetic CaO-based sorbent and a Ni catalyst, Environ. Sci. Technol. 47 (2013) 6007-6014. doi:10.1021/es305113p.

[11] A. Perejón, L.M. Romeo, Y. Lara, P. Lisbona, A. Martínez, J. Manuel, The Calcium-Looping technology for $\mathrm{CO}_{2}$ capture: On the important roles of energy integration and sorbent behavior, Appl. Energy. 162 (2016) 787-807. doi:10.1016/j.apenergy.2015.10.121.

[12] V. Manovic, E.J. Anthony, CaO-based pellets with oxygen carriers and catalysts, Energy and Fuels. 25 (2011) 4846-4853. doi:10.1021/ef2009748.

[13] K. Johnsen, H.J. Ryu, J.R. Grace, C.J. Lim, Sorption-enhanced steam reforming of methane in a fluidized bed reactor with dolomite as $\mathrm{CO}_{2}$-acceptor, Chem. Eng. Sci. 61 (2006) 11951202. doi:10.1016/j.ces.2005.08.022.

[14] K. Johnsen, J.R. Grace, S.S.E.H. Elnashaie, L. Kolbeinsen, D. Eriksen, Modeling of sorption-enhanced steam reforming in a dual fluidized bubbling bed reactor, Ind. Eng. Chem. Res. 45 (2006) 4133-4144. doi:10.1021/ie0511736.

[15] J. Solsvik, Z. Chao, H.A. Jakobsen, Modeling and simulation of bubbling fluidized bed reactors using a dynamic one-dimensional two-fluid model: The sorption-enhanced steammethane reforming process, Adv. Eng. Softw. 80 (2015) 156-173. doi:10.1016/j.advengsoft.2014.09.011.

[16] G. Esteban-díaz, M. V Gil, C. Pevida, D. Chen, F. Rubiera, Effect of operating conditions on the sorption enhanced steam reforming of blends of acetic acid and acetone as bio-oil model compounds, Appl. Energy. 177 (2016) 579-590. doi:10.1016/j.apenergy.2016.05.149.

[17] J.R. Fernández, I. Martínez, J.C. Abanades, M.C. Romano, Conceptual design of a Ca-Cu chemical looping process for hydrogen production in integrated steelworks, Int. J. Hydrogen 
Energy. 42 (2017) 11023-11037. doi:10.1016/j.ijhydene.2017.02.141.

[18] S. Noorman, M.V.S. Annaland, H. Kuipers, Packed Bed Reactor Technology for ChemicalLooping Combustion, Ind. Eng. Chem. Res. 46 (2007) 4212-4220. doi: 10.1021/ie061178i.

[19] B. Balasubramanian, A.L. Ortiz, S. Kaytakoglu, D.P. Harrison, Hydrogen from methane in a single-step process, Chem. Eng. Sci. 54 (1999) 3543-3552. doi:10.1016/S00092509(98)00425-4.

[20] J.R. Fernández, J.M. Alarcón, J.C. Abanades, Investigation of a Fixed-Bed Reactor for the Calcination of $\mathrm{CaCO}_{3}$ by the Simultaneous Reduction of $\mathrm{CuO}$ with a Fuel Gas, Ind. Eng. Chem. Res. 55 (2016) 5128-5132. doi:10.1021/acs.iecr.5b04073.

[21] Z. Li, N. Cai, J. Yang, Continuous Production of Hydrogen from Sorption-Enhanced Steam Methane Reforming in Two Parallel Fixed-Bed Reactors Operated in a Cyclic Manner, Ind. Eng. Chem. Res. 45 (2006) 8788-8793. doi:10.1021/ie061010x.

[22] A. Antzara, E. Heracleous, A.A. Lemonidou, Energy efficient sorption enhanced-chemical looping methane reforming process for high-purity $\mathrm{H}_{2}$ production: Experimental proof-ofconcept, Appl. Energy. 180 (2016) 457-471. doi:10.1016/j.apenergy.2016.08.005.

[23] L. Barelli, G. Bidini, F. Gallorini, SE-SR with sorbents based on calcium aluminates: Process optimization, Appl. Energy. 143 (2015) 110-118. doi:10.1016/j.apenergy.2014.12.066.

[24] J.R. Fernández, J.C. Abanades, R. Murillo, Modeling of sorption enhanced steam methane reforming in an adiabatic fixed bed reactor, Chem. Eng. Sci. 84 (2012) 1-11. doi:10.1016/j.ces.2012.07.039.

[25] J.. Alarcón, J.R. Fernández, $\mathrm{CaCO}_{3}$ calcination by the simultaneous reduction of $\mathrm{CuO}$ in a $\mathrm{Ca} / \mathrm{Cu}$ chemical looping process, Chem. Eng. Sci. 137 (2015) 254-267. doi:10.1016/j.ces.2015.06.030.

[26] Z.S. Li, N.S. Cai, Modeling of multiple cycles for sorption-enhanced steam methane reforming and sorbent regeneration in fixed bed reactor, Energy and Fuels. 21 (2007) 29092918. doi:10.1021/ef070112c.

[27] S.K. Park, T.S. Kim, Comparison between pressurized design and ambient pressure design of hybrid solid oxide fuel cell-gas turbine systems, J. Power Sources. 163 (2006) 490-499. doi:10.1016/j.jpowsour.2006.09.036.

[28] H.R. Ellamla, I. Staffell, P. Bujlo, B.G. Pollet, S. Pasupathi, Current status of fuel cell based combined heat and power systems for residential sector, J. Power Sources. 293 (2015) 312 328. doi:10.1016/j.jpowsour.2015.05.050.

[29] A. Weber, E. Ivers-Tiffée, Materials and concepts for solid oxide fuel cells (SOFCs) in stationary and mobile applications, J. Power Sources. 127 (2004) 273-283. doi:10.1016/j.jpowsour.2003.09.024.

[30] L. Barelli, G. Bidini, G. Cinti, F. Gallorini, M. Pöniz, SOFC stack coupled with dry reforming, Appl. Energy. 192 (2017) 498-507. doi:10.1016/j.apenergy.2016.08.167.

[31] D.P. Harrison, Sorption-enhanced hydrogen production: A review, Ind. Eng. Chem. Res. 47 (2008) 6486-6501. doi:10.1021/ie800298z. 
[32] E.H. Baker, The calcium oxide-carbon dioxide system in the pressure range 1-300 atmosphere, J. Chem. Soc. (Resumed). (1962) 464-470.

[33] V. Manovic, E.J. Anthony, Lime-based sorbents for high-temperature $\mathrm{CO}_{2}$ capture-a review of sorbent modification methods, Int. J. Environ. Res. Public Health. 7 (2010) 3129-3140. doi:10.3390/ijerph7083129.

[34] D. Beruto, A.W. Searcy, Calcium oxides of high reactivity, Nature. 263 (1976) 221-222. doi:10.1038/263221a0.

[35] S. Dash, M. Kamruddin, P.K. Ajikumar, A.K. Tyagi, B. Raj, Nanocrystalline and metastable phase formation in vacuum thermal decomposition of calcium carbonate, Thermochim. Acta. 363 (2000) 129-135. doi:10.1016/S0040-6031(00)00604-3.

[36] B.B. Sakadjian, M. V. Iyer, H. Gupta, L.S. Fan, Kinetics and structural characterization of calcium-based sorbents calcined under subatmospheric conditions for the high-temperature $\mathrm{CO}_{2}$ capture process, Ind. Eng. Chem. Res. 46 (2007) 35-42. doi:10.1021/ie060214a.

[37] L.-S. Fan, H. Gupta, M. Iyer, Separation of Carbon Dioxide From Gas Mixtures By Calcium Based Reaction Separation, U.S. Patent No 8,226,917. 24 jul (2012).

[38] E.R. Van Selow, P.D. Cobden, P. a Verbraeken, J.R. Hufton, R.W. Van Den Brink, Carbon Capture by Sorption-Enhanced Water-Gas Shift Reaction Process using Hydrotalcite-Based Material, Ind. Eng. Chem. Res. 48 (2009) 4184-4193. doi:10.1021/ie801713a.

[39] P.E. Dodds, I. Staffell, A.D. Hawkes, F. Li, P. Grünewald, W. McDowall, et al., Hydrogen and fuel cell technologies for heating: A review, Int. J. Hydrogen Energy. 40 (2015) 20652083. doi:10.1016/j.ijhydene.2014.11.059.

[40] A.F. Massardo, F. Lubelli, Internal reforming solid oxide fuel cell-gas turbine combined cycles (IRSOFC-GT). Part A: cell model and cycle thermodynamic analysis, J. Eng. Gas Turbines Power. 122 (2015) 27-35. doi:10.1115/1.483187.

[41] S.N.R. Isfahani, A. Sedaghat, A hybrid micro gas turbine and solid state fuel cell power plant with hydrogen production and $\mathrm{CO}_{2}$ capture, Int. J. Hydrogen Energy. 41 (2016) 9490-9499. doi:10.1016/j.ijhydene.2016.04.065.

[42] I. Iliuta, R. Tahoces, G. Patience, Chemical-looping combustion process: Kinetics and mathematical modeling, AIChE J. 56 (2010) 1063-1079. doi:10.1002/aic.

[43] J.G. Xu, G.F. Froment, Methane Steam Reforming, Methanation and Water-Gas Shift .1. Intrinsic Kinetics, AIChE J. 35 (1989) 88-96. doi:10.1002/aic.690350109.

[44] L.S. Ferreira, J.O. Trierweiler, Modeling and simulation of the polymeric nanocapsule formation process, IFAC Proc. Vol. 7 (2009) 405-410. doi:10.1002/aic.

[45] I. Martínez, G. Grasa, R. Murillo, B. Arias, J.C. Abanades, Kinetics of calcination of partially carbonated particles in a Ca-looping system for $\mathrm{CO}_{2}$ capture, Energy and Fuels. 26 (2012) 1432-1440. doi:10.1021/ef201525k.

[46] J.R. Fernández, J.C. Abanades, G. Grasa, Modeling of sorption enhanced steam methane reforming-Part II: Simulation within a novel $\mathrm{Ca} / \mathrm{Cu}$ chemical loop process for hydrogen production, Chem. Eng. Sci. 84 (2012) 12-20. doi:10.1016/j.ces.2012.07.050. 
[47] D. Gunn, Mixing in Packed and Fluidised Beds, Chem. Eng. J. 219 (1968) CE153-CE172.

[48] J.M.P.Q. Delgado, A critical review of dispersion in packed beds, Heat Mass Transf. 42 (2006) 279-310. doi:10.1007/s00231-005-0019-0.

[49] J.B. Butt, Mass transfer in heterogeneous catalysis, C.N. Satterfield, Massachussetts Institute of Technlogy Press, Cambridge, Mass. (1970). AIChE J., 509-510. doi:

10.1002/aic.690160303.

[50] R.W. Breault, A review of gas-solid dispersion and mass transfer coefficient correlations in circulating fluidized beds, Powder Technol. 163 (2006) 9-17.

doi:10.1016/j.powtec.2006.01.009.

[51] J. Solsvik, H.A. Jakobsen, A two property catalyst/sorbent pellet design for the sorptionenhanced steam-methane reforming process: Mathematical modeling and numerical analysis, Energy Procedia. 26 (2012) 31-40. doi:10.1016/j.egypro.2012.06.007.

[52] D.E. Mears, Diagnostic Criteria for Heat Transport Limitations in Fixed Bed Reactors, J. Catal. 20 (1971) 127-131.

[53] L. Han, Z. Zhou, G.M. Bollas, Heterogeneous modeling of chemical-looping combustion. Part 2: Particle model, Chem. Eng. Sci. 113 (2014) 116-128. doi:10.1016/j.ces.2014.03.030.

[54] M.S. Shafeeyan, W.M.A. Wan Daud, A. Shamiri, A review of mathematical modeling of fixed-bed columns for carbon dioxide adsorption, Chem. Eng. Res. Des. 92 (2014) 961-988. doi:10.1016/j.cherd.2013.08.018.

[55] O. Levenspiel, Chemical reaction engineering, 3rd ed. (2002). John Wiley \& Sons, New York.

[56] A. Antzara, E. Heracleous, A.A. Lemonidou, Development of CaO-based Mixed Oxides as Stable Sorbents for Post-Combustion $\mathrm{CO}_{2}$ capture via Carbonate Looping, Energy Procedia. 63 (2014) 2160-2169. doi:10.1016/j.egypro.2014.11.235.

[57] L. Han, Z. Zhou, G.M. Bollas, Heterogeneous modeling of chemical-looping combustion. Part 1: Reactor model, Chem. Eng. Sci. 104 (2013) 233-249. doi:10.1016/j.ces.2013.09.021.

[58] J.R. Rostrup-Nielsen, J. Sehested, J.K. Norskov, Hydrogen and synthesis gas by steam and $\mathrm{CO}_{2}$ reforming, Adv. Catal. 47 (2002) 65-139. doi:https://doi.org/10.1016/S03600564(02)47006-X.

[59] Harrison, L. Ortiz, Hydrogen production using sorption-enhanced reaction, Ind. Eng. Chem. Res. 40 (2001) 5102-5109.

[60] M. Kavosh, K. Patchigolla, E.J. Anthony, J.E. Oakey, Carbonation performance of lime for cyclic $\mathrm{CO}_{2}$ capture following limestone calcination in steam/ $\mathrm{CO}_{2}$ atmosphere, Appl. Energy. 131 (2014) 499-507. doi:10.1016/j.apenergy.2014.05.020.

[61] H.P. Hamers, M.C. Romano, V. Spallina, P. Chiesa, F. Gallucci, M.V.S. Annaland, Comparison on process efficiency for CLC of syngas operated in packed bed and fluidized bed reactors, Int. J. Greenh. Gas Control. 28 (2014) 65-78. doi:10.1016/j.ijggc.2014.06.007.

[62] V. Spallina, P. Chiesa, E. Martelli, F. Gallucci, M.C. Romano, G. Lozza, et al., Reactor 
design and operation strategies for a large-scale packed-bed CLC power plant with coal syngas, Int. J. Greenh. Gas Control. 36 (2015) 34-50. doi:10.1016/j.ijggc.2015.01.025.

[63] V.D. Chaudhari, A.D. Desai, Performance Evaluation of Vacuum System: Pump-down Time, International Journal of Scientific \& Engineering Research 2 (2011) 1-4.

[64] Agilent Technologies Italia - Vacuum pumps - product technical data. http://www.agilent.com (last accessed 29/03/2017).

[65] S. Ergun, A. A. Orning, Fluid Flow through Randomly Packed Columns and Fluidized Beds, Ind. Eng. Chem. 41 (1949) 1179-1184. doi:10.1021/ie50474a011.

[66] M.H. Halabi, M.H.J.M. de Croon, J. van der Schaaf, P.D. Cobden, J.C. Schouten, Modeling and analysis of autothermal reforming of methane to hydrogen in a fixed bed reformer, Chem. Eng. J. 137 (2008) 568-578. doi:10.1016/j.cej.2007.05.019.

[67] M. Ryden, A. Lyngfelt, Hydrogen and power production with integrated $\mathrm{CO}_{2}$ capture by chemical looping reforming, in: Proc. 7th Int. Conf. Greenh. Gas Control Technol., Vancouver, 2004: pp. 125-134.

[68] R. Perry, D.W. Green, Perry's Chemical Engineer's Handbook, in: 7th ed. (2017), McGrawHill, New York.

[69] A. Coppola, R. Solimene, P. Bareschino, P. Salatino, Mathematical modeling of a two-stage fuel reactor for chemical looping combustion with oxygen uncoupling of solid fuels, Appl. Energy. 157 (2015) 449-461. doi:10.1016/j.apenergy.2015.04.052.

[70] G. Kolios, B. Glöckler, A. Gritsch, A. Morillo, G. Eigenberger, Heat-integrated reactor concepts for hydrogen production by methane steam reforming, Fuel Cells. 5 (2005) 52-65. doi:10.1002/fuce.200400065.

[71] F.P. Incropera, D.P. DeWitt, T.L. Bergman, A.S. Lavine, Fundamental of Heat and Mass Transfer, 3rd ed. (1990), Wiley, New York.

[72] G. Diglio, P. Bareschino, E. Mancusi, F. Pepe, Novel quasi -autothermal hydrogen production process in a fixed-bed using a chemical looping approach: A numerical study, Int. J. Hydrogen Energy. 42 (2017) 15010-15023. doi:10.1016/j.ijhydene.2017.05.017.

[73] G. Diglio, D.P. Hanak, P. Bareschino, E. Mancusi, F. Pepe, F. Montagnaro, V. Manovic, Techno-economic analysis of sorption-enhanced steam methane reforming in a fixed bed reactor network integrated with fuel cell, J. Power Sources. 364 (2017) 41-51. doi:10.1016/j.jpowsour.2017.08.005.

[74] J. Li, G. Cao, X. Zhu, H. Tu, Two-dimensional dynamic simulation of a direct internal reforming solid oxide fuel cell, J. Power Sources. 171 (2007) 585-600. doi:10.1016/j.jpowsour.2007.07.029.

[75] J. Larminie, A. Dicks, Fuel Cell Systems Explained, 2001. doi:10.1016/S03787753(00)00571-1.

[76] J. Pirkandi, M. Ghassemi, M.H. Hamedi, R. Mohammadi, Electrochemical and thermodynamic modeling of a CHP system using tubular solid oxide fuel cell (SOFC-CHP), J. Clean. Prod. 29-30 (2012) 151-162. doi:10.1016/j.jclepro.2012.01.038. 
[77] J. Sarkar, S. Bhattacharyya, Operating characteristics of transcritical $\mathrm{CO}_{2}$ heat pump for simultaneous water cooling and heating, Arch. Thermodyn. 33 (2012) 23-40. doi:10.1002/er.

[78] J.H. Hirschenhofer, D.B. Stauffer, R.R. Engleman, M.G. Klett. Fuel Cell Handbook, 7th ed. (2004), Business/Technology Books, USA.

[79] A. Franzoni, L. Magistri, A. Traverso, A.F. Massardo, Thermoeconomic analysis of pressurized hybrid SOFC systems with $\mathrm{CO}_{2}$ separation, Energy. 33 (2008) 311-320. doi:10.1016/j.energy.2007.07.008. 